Article

\title{
An Integrated Method for Landscape Assessment: Application to Santiago de Cuba Bay, Cuba
}

\author{
Seweryn Zielinski ${ }^{1}\left(\mathbb{D}\right.$, Celene B. Milanés ${ }^{2, *} \mathbb{D}$, Elena Cambon ${ }^{3}$, Ofelia Perez Montero ${ }^{4}\left(\mathbb{D}\right.$, Lourdes Rizo $^{3}$, \\ Andres Suarez ${ }^{2}\left(\mathbb{D}\right.$, Benjamin Cuker ${ }^{5}$ and Giorgio Anfuso ${ }^{6, *}$ (D) \\ 1 Department of Hospitality and Tourism Management, Sejong University, Seoul 05006, Korea; \\ zielinski@sejong.ac.kr \\ 2 GeMarc and GESSA Research Groups, Department of Civil and Environmental Engineering, \\ Universidad de la Costa, Calle 58\#55-66, Barranquilla 080001, Colombia; asuarez24@cuc.edu.co \\ 3 Faculty of Buidings, Universidad de Oriente, Las Américas Avenue s/n, Santiago de Cuba CP 90400, Cuba; \\ ecambon24@gmail.com (E.C.); lourdesrizo@uo.edu.cu (L.R.) \\ 4 Multidisciplinary Study Center of Coastal Zone, Universidad de Oriente, Las Américas Avenue s/n, \\ Santiago de Cuba CP 90400, Cuba; ofelia@uo.edu.cu \\ 5 Department of Marine and Environmental Science, Hampton University, Hampton, VA 23668, USA; \\ benjamin.cuker@hamptonu.edu \\ 6 Faculty of Marine and Environmental Sciences, University of Cádiz, Polígono Río San Pedro s/n, \\ 11510 Puerto Real, Spain \\ * Correspondence: cmilanes1@cuc.edu.co (C.B.M.); giorgio.anfuso@uca.es (G.A.)
}

Citation: Zielinski, S.; Milanés, C.B.; Cambon, E.; Perez Montero, O.; Rizo, L.; Suarez, A.; Cuker, B.; Anfuso, G. An Integrated Method for Landscape Assessment: Application to Santiago de Cuba Bay, Cuba. Sustainability 2021, 13, 4773. https://doi.org/ $10.3390 /$ su13094773

Academic Editor: Elena Rada

Received: 7 April 2021

Accepted: 21 April 2021

Published: 24 April 2021

Publisher's Note: MDPI stays neutral with regard to jurisdictional claims in published maps and institutional affiliations.

Copyright: (c) 2021 by the authors. Licensee MDPI, Basel, Switzerland. This article is an open access article distributed under the terms and conditions of the Creative Commons Attribution (CC BY) license (https:// creativecommons.org/licenses/by/ $4.0 /)$.

\begin{abstract}
Human activities often drive landscape degradation and the associated loss of value. This paper describes a method that, by integrating multiple factors, characterize landscape value to establish relevant and effective management practices. The new integrated method for landscape assessment (IMLA) is a four-step model that includes: (i) establishment of a general theoretical basis for sustainability relevant metrics; (ii) characterization of the landscape; (iii) landscape valuation; (iv) recommendations for landscape value management. Each step includes different interactive components of analysis. The new IMLA considers the potential range of values associated with each landscape unit and facilitates sustainable landscape management. The method is systematic and includes both inductive and deductive reasoning. Its articulation is represented in the conjunction and overlapping of all factors and variables considered. IMLA was tested in Santiago de Cuba Bay (Cuba) and used to determine five landscape scopes, eight first-order landscape units and 29 s-order units. It proved to be a useful tool to establish landscape values and sound management strategies. Application of IMLA in Cuba will help local authorities institute land-use plans and to establish decision-making processes that include valuation of cultural landscapes.
\end{abstract}

Keywords: landscape units; characterization value management; sustainability; scenarios; coastal zone

\section{Introduction}

An appropriate tool for the effective and sustainable management of landscape is required to preserve the beauty and functionality of natural areas [1]. This is a complex problem that must incorporate evolving ideas of how to value landscapes and landscape gaps (surrounding areas) in a way that encompasses a variety of stakeholder perspectives. These include visual, socio-cultural, natural and other attributes. Multiple methodologies to analyze landscapes exist and most of them use a territorial geoecological approach to delimitate landscape units, e.g., "Landscape Units" [2-7], "Homogeneous Units of Land" [8] "Ecological Units" [9] or "Environmental Units" [10,11].

Delimitation of landscape units primarily using physical-geographical criteria does not consider the value of scenic and cultural attributes [12-15]. Some authors propose methodological frameworks for the study of visual landscapes $[4,10,12,14,16-18]$ or for the 
spatial characterization of landscape functions $[7,19]$. These primarily consider physicalgeographical aspects to define landscape units and usually ignore scenic factors $[4,10]$. Such approaches fail to integrate the full suite of factors needed to delimit landscape units for effective management.

In some cases, more is less, as excessive numbers of variables for delimitation of landscape units fail to provide sufficient integration for informed decisions. Thematic maps reflect characterization of those variables $[3,4,7,10,14,18,20,21]$. Techniques of landscape characterization designed to drive practical decision- making processes in fields such as, spatial planning, development control and "countryside" management [22], may lack effective characterization processes. Establishing the value of landscape types must precede characterization efforts in order to ensure timely and effective decision-making.

Effective landscape valuation process produces better management practices [23]. Some approaches are incomplete, as they focus on visual quality and landscape fragility but miss other considerations [8,24-27]. Some authors identify kinds of values assigned to landscape and describe their characteristics but without mentioning valuation criteria [28-30]. Other authors doubt the usefulness of including multiple variables in one single assessment $[15,30-34]$.

Sometimes, historic information is included in the landscape assessment and characterization process $[8,35,36]$, but generally, most of the methods do not consider the social-historical conditions of landscape to understand the corresponding evolution and transformations associated with different cultural processes.

Landscapes are complex, spatially heterogeneous systems with many properties and values [37-39]. A landscape promotes perceptions, values or expectations that differ spatially and among individuals [40]. Studies of how landscape can be methodologically characterized and valued are limited. Approaches to assess landscape patterns and characteristics include natural, cultural, visual and ecological aspects [39]. Brabyn [41] indicates that both the aesthetic and biodiversity values of landscapes are important but understanding and managing them requires different sets of information [39].

Various authors consider a wide range of variables when characterizing landscapes, yet some of them focusing on aesthetics aspects $[3-5,7,10,13,20,21,42]$. In other studies, the values assigned to landscape are empirically or subjectively determined, without taking into consideration all the variables influencing landscape, such as the ones derived from natural and anthropogenic components [25-27]. Ultimately, the landscape value is subjective and a human construct [43]. Despite the urgency for a more effective approach to valuation of landscapes in this era of climate change [44], no studies to date address the way in which professionals develop metrics to do such [45].

The present research addresses the following questions:

(1) What kind of research is required to characterise and value landscapes for sustainable management?

(2) What set of factors, variables and sub-variables must be considered to characterize and value landscape for management?

(3) How can a method for characterizing and valuing landscapes be put into practice?

(4) What results are generated from applying the Integrated Method for Landscape Assessment (IMLA) in a real-life scenario?

\section{Methods}

Three different methods were used in this study. The synthetic-analytic approach [46] developed a critical review to analyze and synthesize several theories, concepts and methodologies about landscape to disarticulate the different landscape components and to design factors and variables influencing landscape assessment. The systemic-structural method and the induction-deduction method [47] were used for the holistic and systematic interpretation of landscape, as well as for designing the new approach (IMLA) proposed in this paper. This included consideration of each of the different stages and variables influencing the landscape. 


\subsection{Design of the Set of Variables for Landscape Valuation}

There is a vast range of landscape assessment and valuing methods that show similarities/differences. This paper identified the main similarities and differences among the different variables used herein in order to propose a set of metrics to consolidate the needed information (Table 1). We analyzed three kinds of factors to develop the IMLA:

(1) Natural Factors: Environmental components on which human activities are based [3$6,20,21]$

(2) Cultural Factors: Socio-economic components of the existing culture responsible for using and transforming the corresponding environmental conditions for its own development [48-55].

(3) Scenic Factors: Visual components, which set the landscape apart and result from the relationship between natural and cultural components $[13,14,56]$.

Those three factors constitute the most general parts of the system and the landscape's main elements are incorporated into it: nature, culture and scenery. The proposed variables constitute the system components representing the essential landscape characteristics of each factor (Table 2). The new factors and variables selected were offered for discussion at three international workshops and at two professional committees. They were selected international and national experts representing different research fields, such as architects, urban planners, sociologists, geographers and historians. Each of such experts had more than 15 years of experience in his respective field of study, i.e., heritage, integrated management of coastal zones and resilient and sustainable cities. In one of them, international landscape experts from Spain, Canada, Brazil and Portugal provided their criteria and assessed the different levels of analysis to put the method into practice. In order to gain some perspectives on the organizational structure most appropriate to design IMLA a survey was proposed to gather in-depth information on attitudes regarding each of the factors and variables considered. In addition, the questionnaire online included some open-ended queries. The survey was structured in three sections, with information concerning:

(1) respondents;

(2) main variables for landscape characterization;

(3) types of values associated with the landscape.

To define the sample size of the experts to interview we used Inferential Statistics [57]. This constitutes an excellent technique for determining a sample of experts in a previously established universe. A total of 90 experts from 15 provinces of Cuba formed the final sample for our analysis, i.e., 23 in Eastern Region; 30 in Central and 37 in Western Region. Cuban experts were consulted online. The reality observation technique [58] was applied during fieldwork and when identifying the different elements that influence and determine the specific landscaping characteristics of the visual gap from the study area (Santiago de Cuba Bay). Other studies helped identify the latest principal transformations in Santiago de Cuba Bay [59-61]. The Photo-Interpretation Technique of satellite images and 2020 Google Earth Software supported cartographic, topographic and toponymical regional bases at scales of 1:50,000, 1:25,000 and 1:10,000 [62]. The fieldwork was carried out between January and June 2020, always in the morning ( $8 \mathrm{am}-12 \mathrm{pm})$. 
Table 1. Values associated with the landscape and the sites analyzed in different approaches abstracted from the literature.

\begin{tabular}{|c|c|c|c|c|c|c|c|c|c|c|c|c|c|c|c|c|c|}
\hline \multirow[b]{2}{*}{$\begin{array}{c}\text { Types of Values/ } \\
\text { Authors }\end{array}$} & \multirow[b]{2}{*}{ 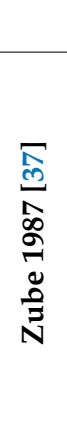 } & \multicolumn{10}{|c|}{ Values Associated with Landscapes } & \multicolumn{6}{|c|}{ Values Associated with Sites } \\
\hline & & 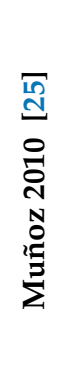 & 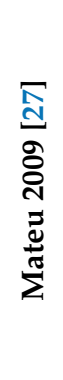 & 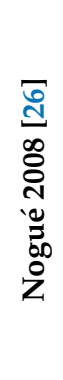 & 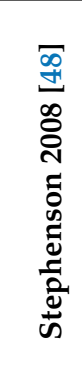 & 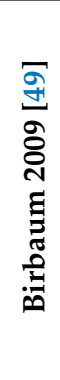 & 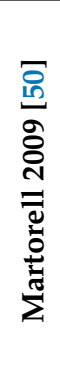 & 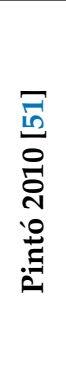 & 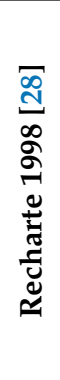 & 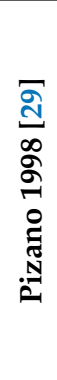 & 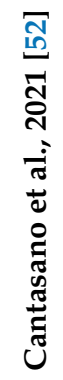 & 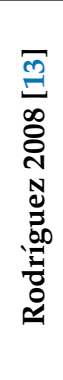 & 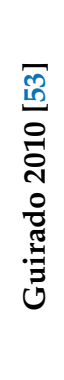 & 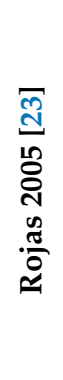 & 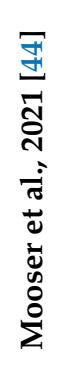 & 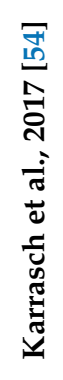 & Total \\
\hline Natural & & & & $\mathrm{x}$ & & & $x$ & & $x$ & & $x$ & & $x$ & & $\mathrm{x}$ & $\mathrm{x}$ & 7 \\
\hline Cultural & & & & & $x$ & $x$ & $\mathrm{x}$ & $x$ & $x$ & $x$ & $x$ & & & & & & 7 \\
\hline Aesthetic & & $x$ & $x$ & $x$ & & $x$ & & $\mathrm{x}$ & & $x$ & & & & $x$ & $x$ & & 8 \\
\hline Scenic & & & & & & & & & $x$ & & $x$ & & & & $x$ & & 3 \\
\hline Environmental & & $x$ & & & & & & $x$ & & & $\mathrm{x}$ & & & & $x$ & $x$ & 5 \\
\hline Social & & $\mathrm{x}$ & & $x$ & & & $x$ & & & & & & & & & $x$ & 4 \\
\hline Territorial & & $x$ & & & & & & & & & & & & & & & 1 \\
\hline Historical & & & & $x$ & & $x$ & & $x$ & $x$ & & $\mathrm{x}$ & & & & $x$ & & 6 \\
\hline Ethnologic & & & & & & & & & & $x$ & & & & & & & 1 \\
\hline Anthropological & & & & & & & & & & $x$ & & & $x$ & & & & 2 \\
\hline Morphotypological & & & & & & & & & & & & $x$ & & & & & 1 \\
\hline Socio-testimonial & & & & & & & & & & & & & & $x$ & $x$ & & 2 \\
\hline Socio-cultural & $x$ & & & & & & & & & & & & & & & & 1 \\
\hline Productive & & & $x$ & $x$ & & & & & & & & & & & & & 2 \\
\hline Symbolic & & & $x$ & $x$ & & & & & & & & & & & & & 2 \\
\hline Religious & & & & $x$ & & & & & & & & & & & & & 1 \\
\hline Artistic & & & & & & & & & & & & & & & $x$ & & 1 \\
\hline Scientific & & & & & & & & & & & & & $x$ & & $x$ & & 2 \\
\hline Archaeological & & & & & & & & & & & & & & & $x$ & & 1 \\
\hline Ecological & & & & $x$ & & & & & & & $x$ & & $x$ & & & $x$ & 4 \\
\hline Economic & & & & & & & & & & & & & & $x$ & & & 1 \\
\hline
\end{tabular}


Table 2. Factors and variables for landscape characterization and valuation.

\begin{tabular}{|c|c|c|}
\hline Factors & Variables for Characterization & Values \\
\hline Natural & $\begin{array}{ll}\text { - } & \text { Relief and Altimetry } \\
\text { - } & \text { Hydrography } \\
\text { - } & \text { Vegetation } \\
\text { - } & \text { Fauna } \\
\text { - } & \text { Climate }\end{array}$ & Natural \\
\hline Cultural & $\begin{array}{ll}\text { - } & \text { Urbanizations } \\
\text { - } & \text { Concentrated rural settlements } \\
\text { - } & \text { Mining industry } \\
\text { - } & \text { Agricultural systems } \\
\text { - } & \text { Infrastructure facilities } \\
\text { - } & \text { Pollution }\end{array}$ & $\begin{array}{c}\text { Cultural } \\
\text { Historical } \\
\text { Social }\end{array}$ \\
\hline Scenic & $\begin{array}{ll}\text { - } & \text { Visual gap } \\
\text { - } & \text { Visibility } \\
\text { - } & \text { Visual components } \\
\text { - } & \text { Physical components } \\
\text { - } & \text { Spatial components }\end{array}$ & Scenic \\
\hline
\end{tabular}

\subsection{Study Area}

Santiago de Cuba Bay, located in the south-eastern region of Cuba, represented an appropriate area to test the feasibility and relevance of IMLA (Figure 1). The visual gap from Santiago de Cuba Bay comprises about $140 \mathrm{~km}^{2}$ and is delimited by a mountainous system at the North, East and West and by the Caribbean Sea in the South. This geographical position creates a large, enclosed space, amphitheater-shaped, facing the sea, where the Bay is the central focus of attention $[18,59]$.

Three important criteria pointed to selecting the Santiago de Cuba Bay to validate the method. First, this Bay is the second important in Cuba [59] and visual gap landscapes have distinctive environmental components due to the rough relief and irregular poly-lobed shape of the basin. Second, Santiago Bay offers a complex urban structure well adapted to its topographic configuration, shape and climate conditions. The integration of those three elements is the reason for the presence of multiple values in the landscape, albeit degraded or deteriorated $[14,18]$. Third, the real value of its landscape is currently unknown and, consequently, its qualities are inadequately managed [14,63]. Substantial increase in urbanization, as well as several changes in the coastal morphology for tourism and industrial development, engendered natural and cultural alterations in the landscape of urban spaces. This caused drastic and constant transformations of coastal zones; mangrove swamps, lagoons, beaches, cliffs and coastal dunes $[60,64,65]$. Therefore, IMLA would provide methodologies for integrated landscape characterization and valuation to improve effective and sustainable landscape value management. 


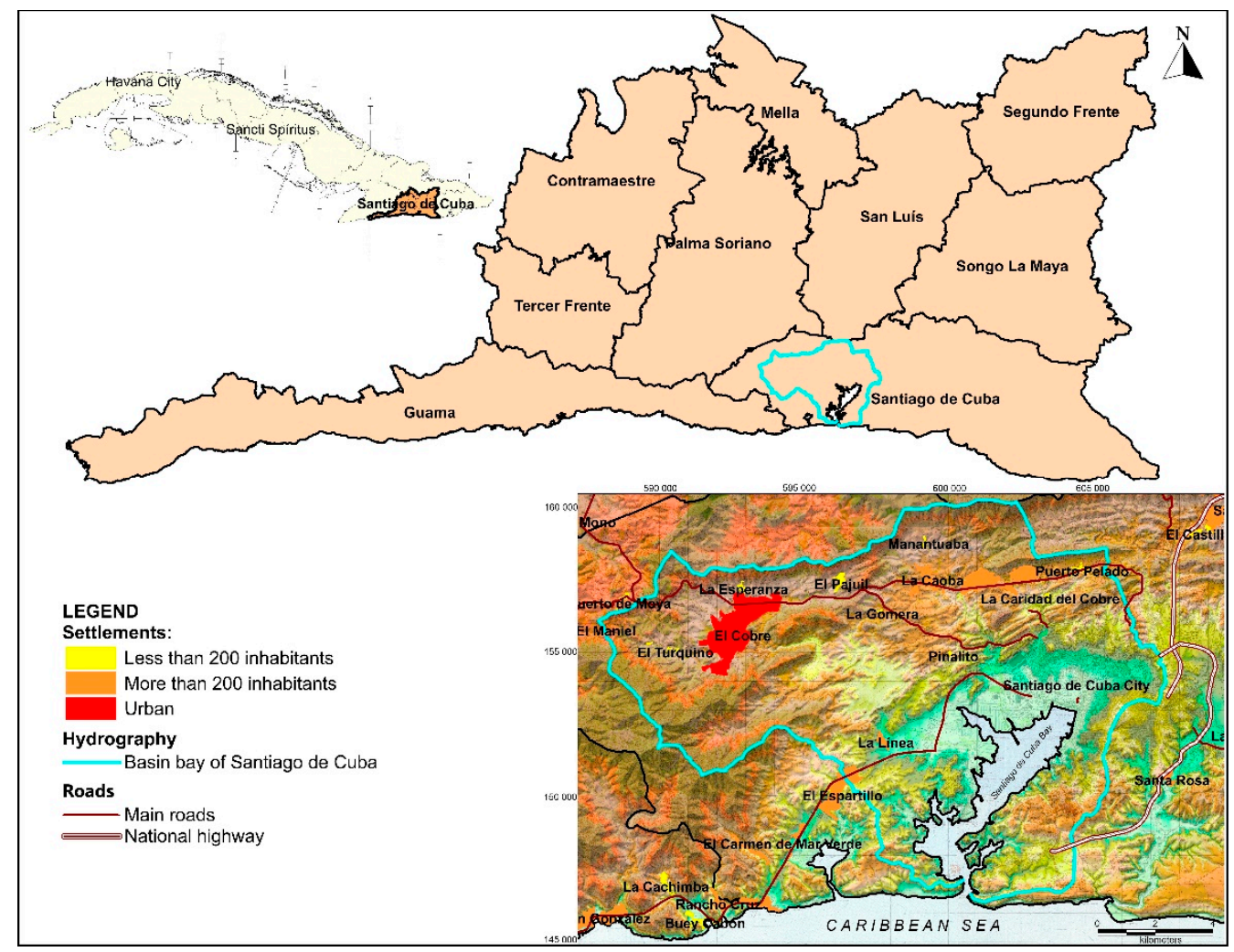

Figure 1. Location of Cuba in the Caribbean Sea and Delimitation of Visual Gap from Santiago de Cuba Bay.

\section{Results}

3.1. New Integrated Method for Landscape Assessment (IMLA)

IMLA conceives landscape as a system composed of different interacting sub-systems. For further valuation, the landscape is divided into different parts and its intrinsic elements structured into smaller units of different hierarchical orders. Additionally, the method comprises four levels of analysis (Figure 2) dialectically related to each other. For a better understanding, the whole process is organized and analyzed from its general aspects to the specifics. 


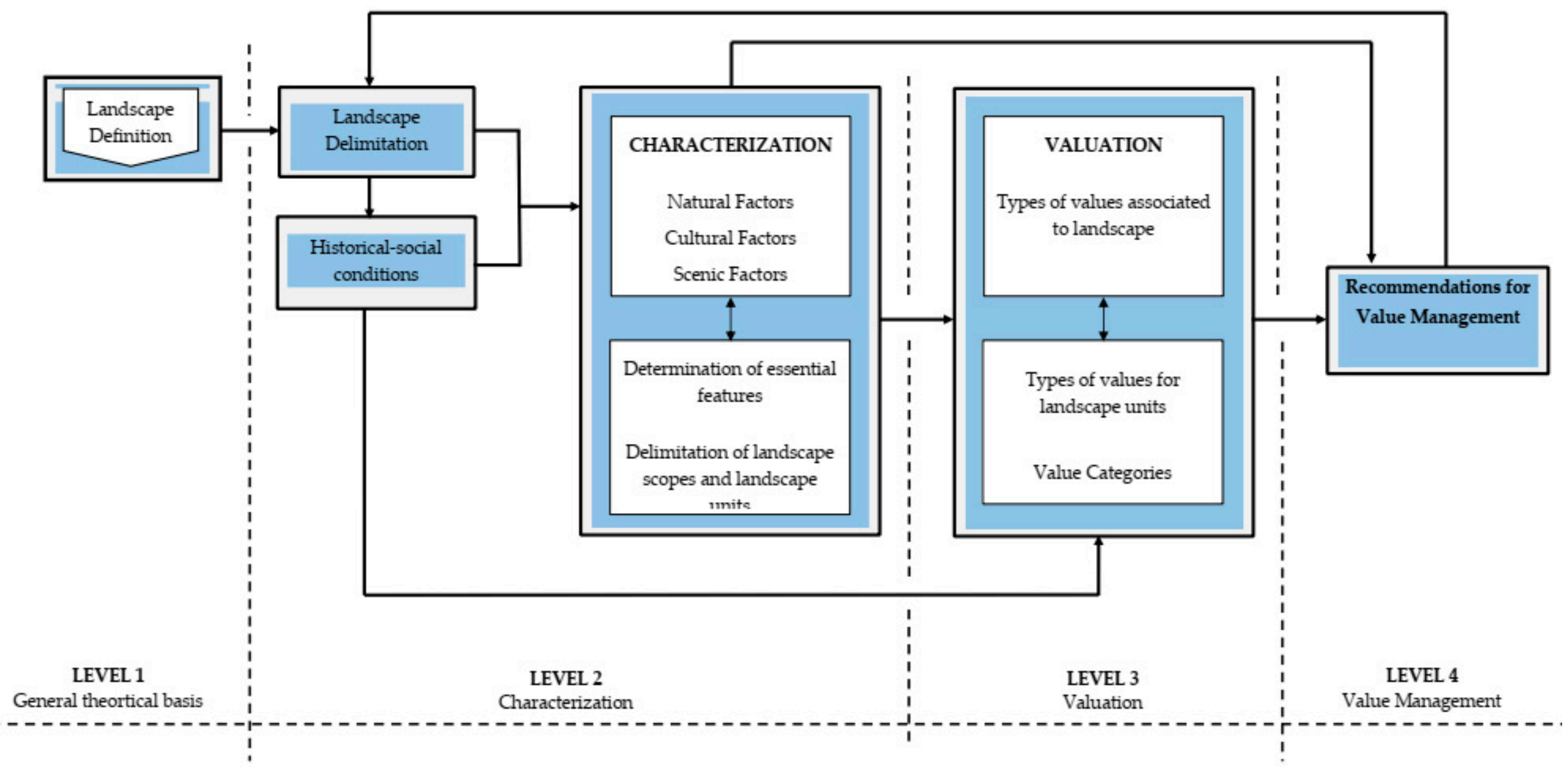

Figure 2. General Scheme of the Integrated Method for Landscape Assessment (IMLA). 
3.1.1. Levels 1 and 2: Definition and Characterization of the Landscape Object of Study

The definition of the landscape to be characterized and assessed is carried out at Level 1, while Level 2 is structured into five different phases:

Delimitation of the subject of study;

(i) Analysis of the socio-historical landscape conditions;

(ii) Landscape characterization according to natural, cultural and scenic factors;

(iii) Determination of essential landscape features;

(iv) Delimitation of landscape surroundings and corresponding units (Figure 3).

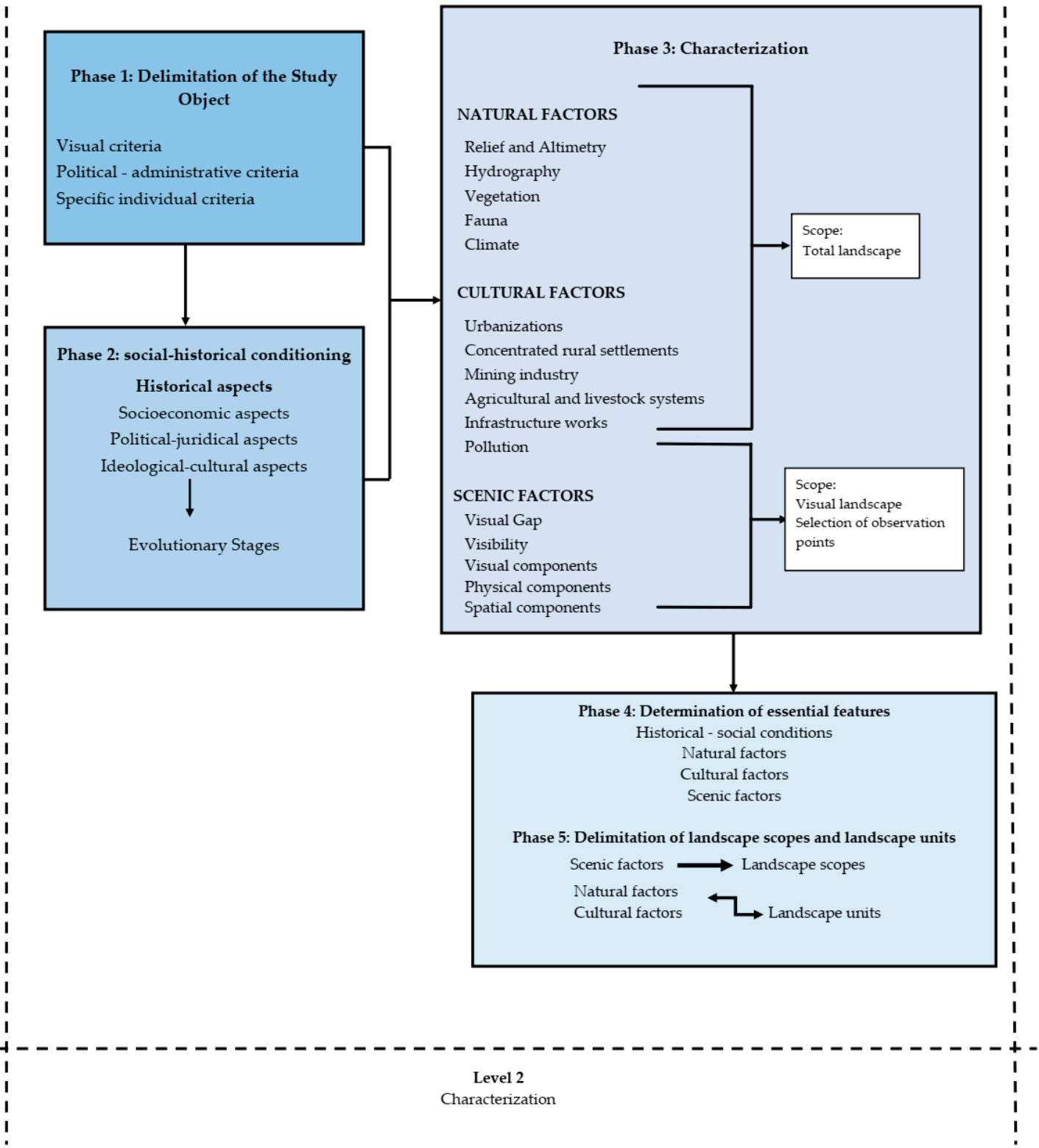

Figure 3. Detailed outline of Level 2 of Landscape Characterization.

In IMLA a Delimitation of the subject of study at Phase 1 is made following three different kind of criteria: (1) visual criteria [4,13,14,17,66]; (2) political-administrative criteria $[5,6,20,21]$ and (3) individual-specific criteria [11,14], related to spaces specially identified by their historical, cultural or geographical circumstances $[35,66]$.

For analyzing the historical-social conditions at Phase 2, the cultural landscape is regarded as the territory with traces of human activity caused by the anthropization 
processes. Special attention is given to landscapes where the level of transformations is generally very high because of the presence of urban, mining-industrial or touristic activities. Consequently, a historical-evolutive study about the landscape follows with the aim of defining the different stages or historical periods affecting the territory. At phase 3, the proposed system of factors, variables and sub-variables characterizes the landscape under study. The Sub-variables explained further on constitute the specific characteristics of every variable (Appendix A).

Five variables help to analyze scenic factors in the areas of landscape observation. The "shape" sub-variable refers to the landscape geometric form of the visual gap (Appendix B). The compactness of the landscape of visual gap indicates the non-visible or shadowy zones of the territory because of the existence of natural or anthropic obstacles. Compact landscape of visual gap means flat land, without obstacles, the content of the landscape completely visible. Hollow landscape of the visual gap refers to rough land, with a great number of visible obstacles (Appendix C). The landscape's scope is delimited according to the visual aspects influenced by the observer's position and area from the surveillance point, (Appendix D).

Phase 4 aims to determine essential landscape features considering those invariant qualities conferring identity to the landscape.

Phase 5 delimits landscape scopes and landscape units according to criteria outlined in Table 3.

Table 3. Criteria to delimit landscape scopes and landscape units.

\begin{tabular}{ccl}
\hline Orders of Landscape Units & & \multicolumn{1}{c}{ Criteria for Delimitation } \\
\hline Landscape scopes & - & Scenic factors. \\
& - & $\begin{array}{l}\text { Homogeneous scenario in terms of space and visibility. } \\
\text { Visual, physical and spatial components, as well as the } \\
\text { characteristics of the visual gap defined by the } \\
\text { observer. }\end{array}$ \\
\hline Units of First Order & - & $\begin{array}{l}\text { Natural factors considered primary factors of the } \\
\text { original landscape shape. } \\
\end{array}$ \\
& - & Relief, hydrography, climate, vegetation and fauna. \\
& - & $\begin{array}{l}\text { Cultural factors considered secondary factors that } \\
\text { identify anthropogenic transformations of the territory. } \\
\text { Units of Second Order }\end{array}$ \\
& - & $\begin{array}{l}\text { Urbanization, element of major landscape impact. } \\
\text { Concentrated rural settlements, agricultural systems, } \\
\text { mining and infrastructure facilities. }\end{array}$ \\
\hline & &
\end{tabular}

\subsubsection{Level 3: Landscape Valuation}

While characterization is an analytical-descriptive practice, valuation is a syntheticevaluative exercise. The types of values associated with landscape are defined in Level 3 (Figure 4). A qualitative scale of the landscape units defines the valuing categories for each of them (Table 4 and Appendix E). Those three categories and their modes of action derived from the recommendations for landscape value management. 


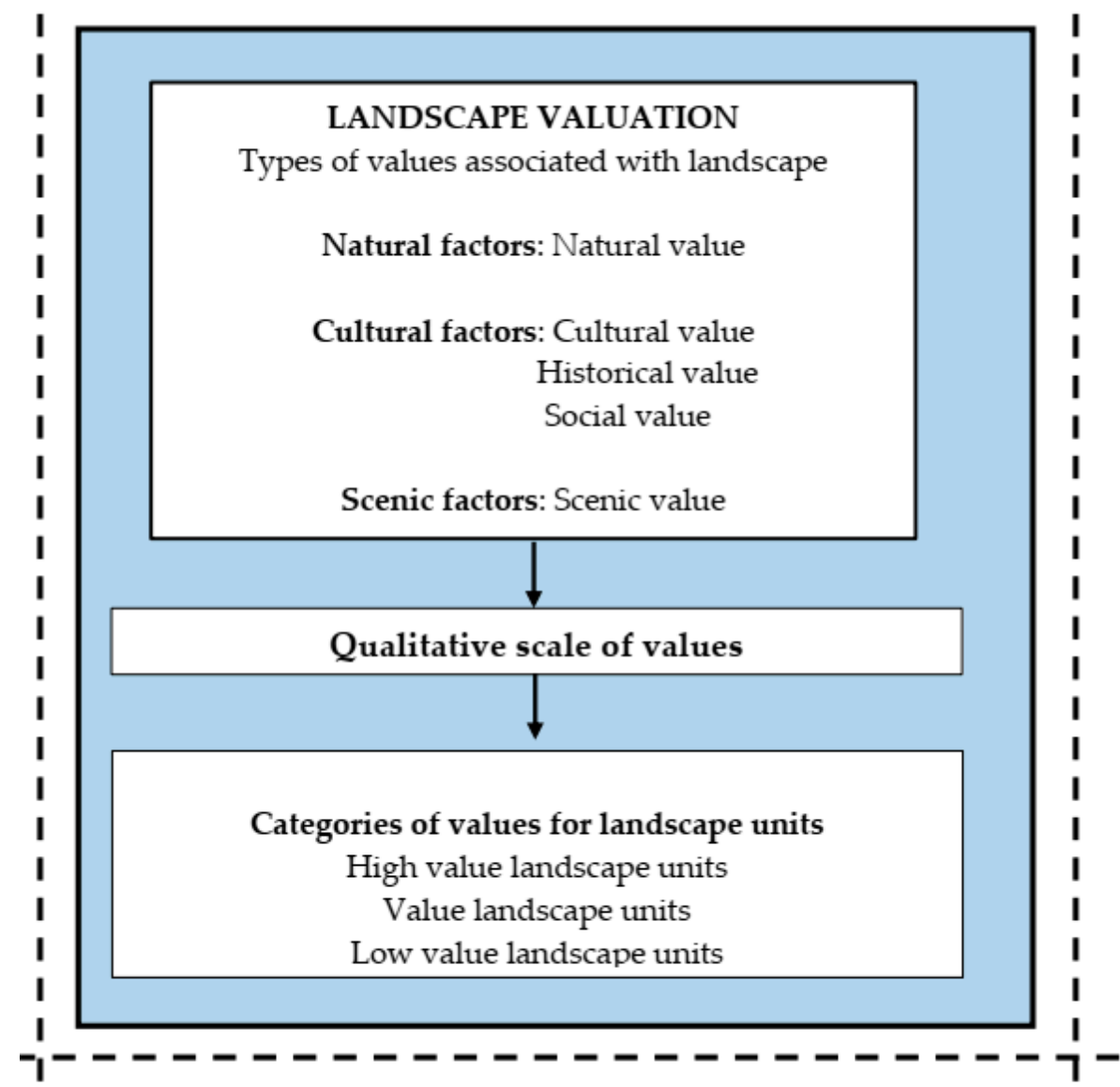

Figure 4. Detailed Scheme of Level 3: Landscape Valuation.

Table 4. Determination of Value Categories for Landscape Units.

\begin{tabular}{|c|c|c|}
\hline Categories & Values for Landscape Units & Criteria for Selection \\
\hline I & High & - $\quad$ More than $70 \%$ of landscape units with high values. \\
\hline II & Medium & $\begin{array}{l}\text { - } \quad 30 \% \text { to } 70 \% \text { of landscape units with high values. } \\
\text { - } \quad \text { More than } 70 \% \text { of landscape units with medium values. }\end{array}$ \\
\hline III & Low & $\begin{array}{l}\text { - Less than } 30 \% \text { of landscape units with high values. } \\
\text { - } \quad \text { More than } 70 \% \text { of landscape units with low values. }\end{array}$ \\
\hline
\end{tabular}

\subsubsection{Level 4: Landscape Value Management}

The final aim of IMLA is to provide a basis for recommendations about preserving and protecting the landscape. Recommendations provide useful guidelines for actions and are formulated at a theoretical level. However, they can be used at a practical level in future projects for management and planning processes [14]. Additionally, recommendations are formulated at a general level regarding landscape, but at a specific for the landscape units that resulted from the valuation processes. The value categories of landscape units are the ones considered for IMLA.

Preservation and integral protection of landscape values are recommended for Category I units. Preservation with modifications that do not affect the landscape values are recommended for Category II units and modifications and/or adaptation for recuperation of landscape values are recommended for units in Category III. These recommendations provide a potential legal framework $[67,68]$. 


\subsection{Validation of the New IMLA at Santiago de Cuba Bay}

We tested IMLA with an analysis of Santiago de Cuba Bay. The venue's historicalsocial conditions featured five evolutive stages during the anthropization process: (1) Prefoundation (before year 1515); (2) Formation of the urban nucleus (1515-1799) associated with the process of conquest and colonization during the "New World Discovery"; (3) Consolidation of the urban nucleus (1800-1898), when Santiago de Cuba was amalgamated as a city and presented predominantly natural landscapes; (4) Urban and rural expansion (1900-1959), when urban and rural activities transformed all landscapes of the visual gap; (5) Industrialization (1960-1992), linked to the industrialization of the visual gap environment, radically altering the landscape $[14,18,60,69,70]$.

Landscape characterization revealed relief and vegetation as most representative of all the natural factors analyzed $[14,61,71]$. Birds were the most representative and important fauna, as well as the most visible animals in landscape. The Bay, with its water mirror, was the most attractive landscape component. Climate in that zone was also a stable component, with few variations and offering good visibility year-round.

Among all cultural factors for Santiago de Cuba urbanization has the greatest influence on landscape, due to the large surface it occupies [72,73]. Agricultural systems alter vegetation color and patterning, dependent on the various types of crops. Particulates and aerosols pollute the air, causing poor transparency and opacity $[59,74,75]$. Linear and punctual built infrastructures dominate the visage.

Only one mining facility is very visible, negatively affecting a small portion of the landscape. Concentrated rural settlements are small and rare.

Visual and spatial components are the most significant scenic factors due to great contrasts in colors, shapes, textures and lines of landscapes and the numerous human constructions. Physical components are important features of landscape scenes including anthropic activities, water features, vegetation and scenic background.

There were 29 potential observation points for the visual gap and 7 were selected as the most representative $[14,18]$. We choose three positions in the water body of the Bay: North, Center and South (Figure 5). No positions were selected for the West since the zone is low, highly industrialized and difficult to access. The observer's position was analyzed for each point (Figures 6-8). In this case, the observer views the landscape from three different angles to note scenery and components.

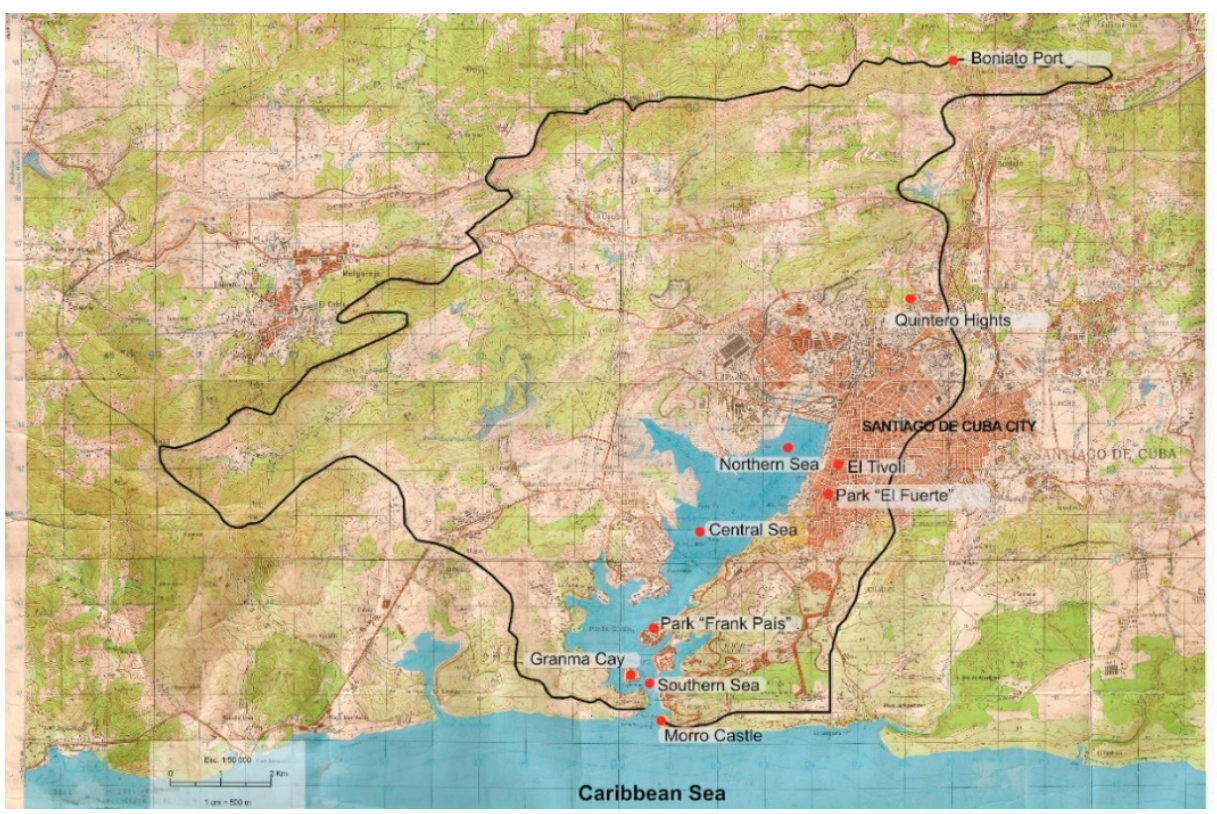

Figure 5. Localization of Landscape Observation Positions. 

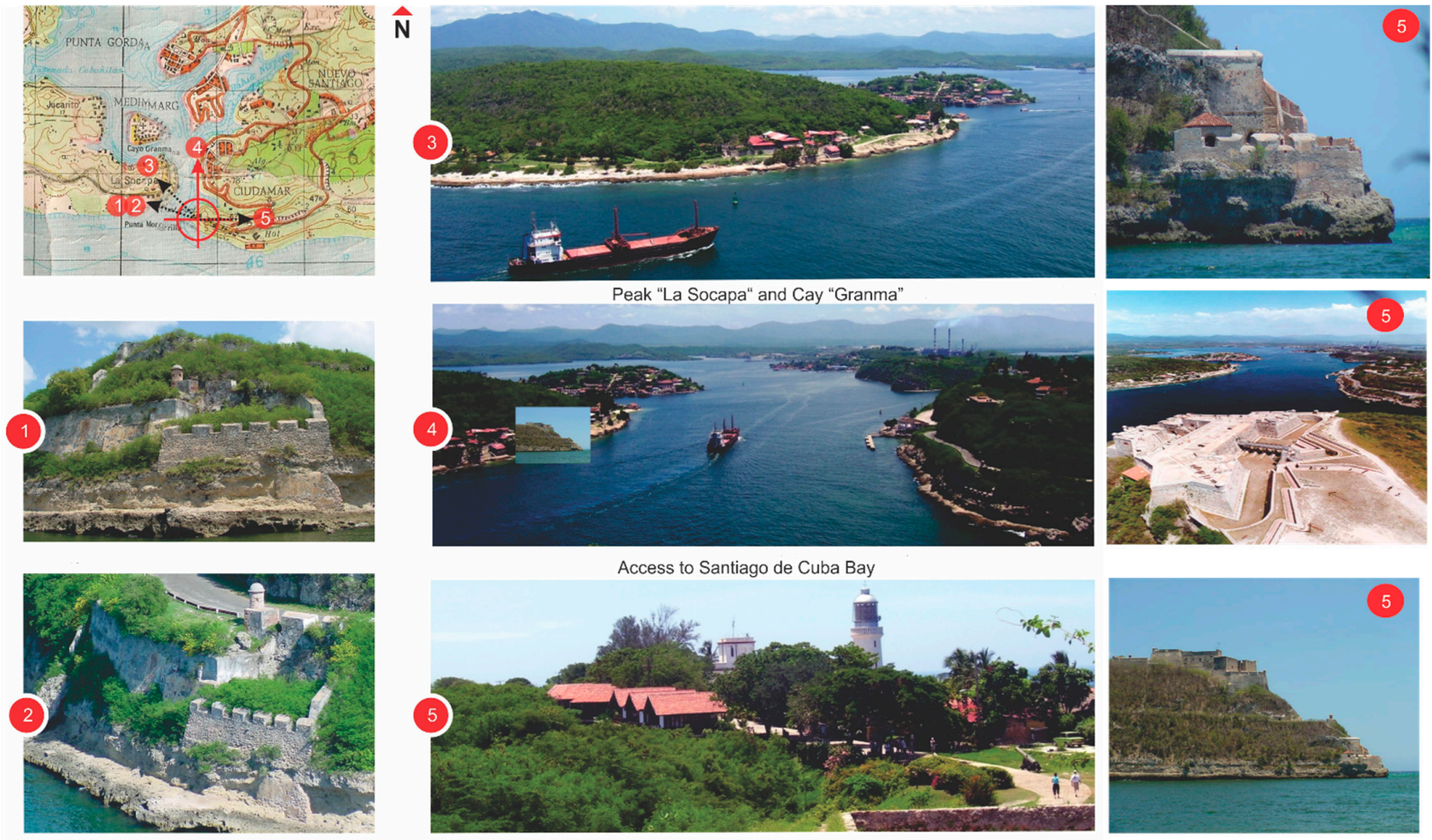

Figure 6. Visuals from "San Pedro de la Roca" Castle.

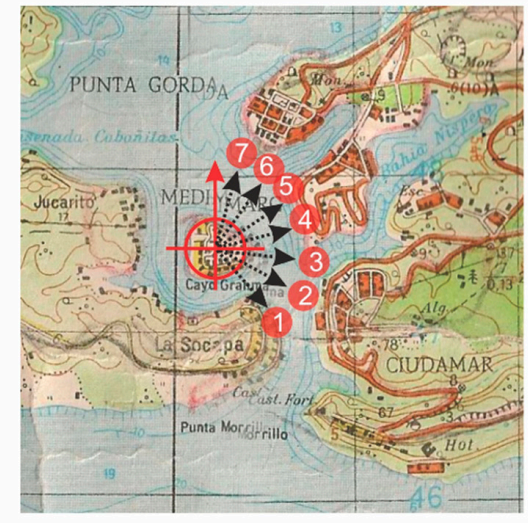

Visuals from "Granma Cay"

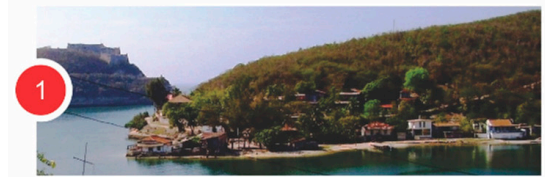

Peak "La Socapa behind and "Granma Cay"
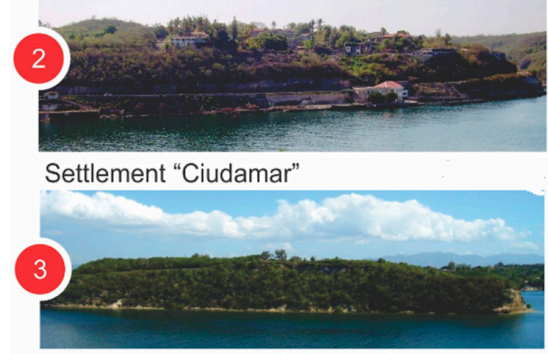

Settlement "Barrio Técnico"

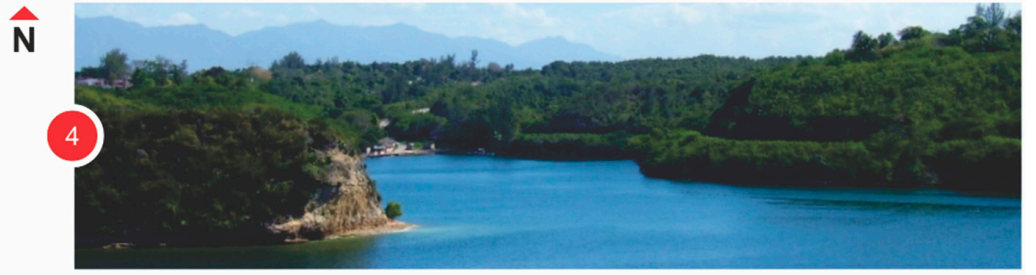

Cove El Níspero

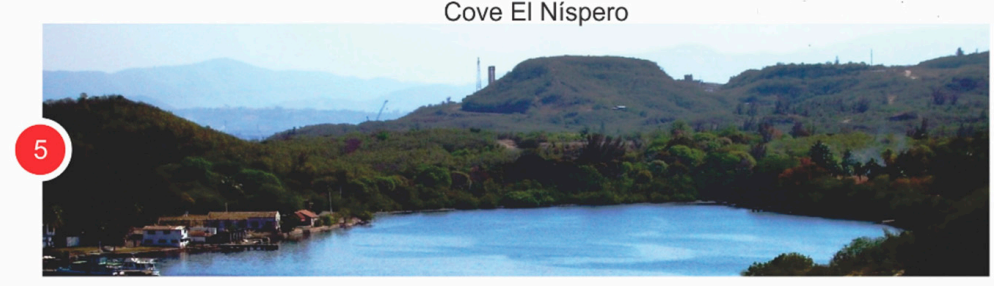

Cove Gaspar

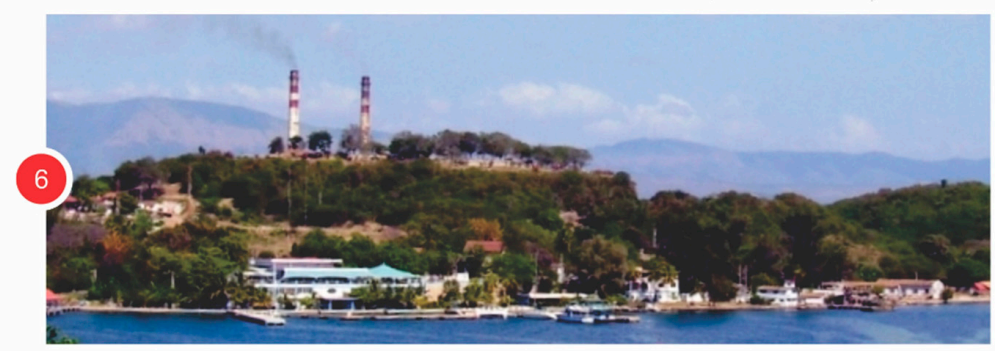

Marine "Marlyn", Frank País" Park and Thermoelectric

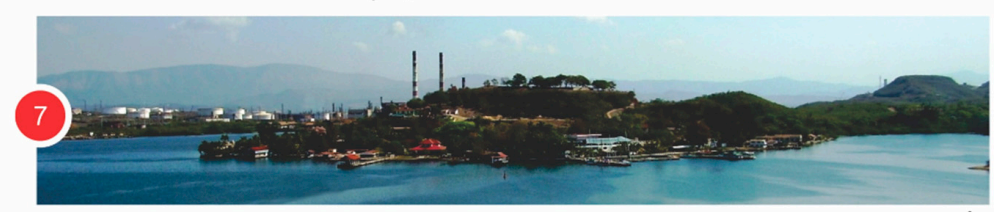

Settlement "Punta Gorda"

Figure 7. Visuals from "Granma" Cay. 


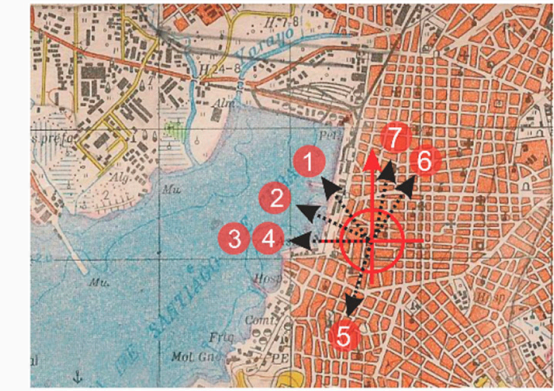

Visuals from "Tivoli" neighborhood

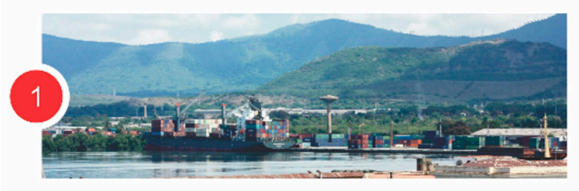

Port "Guillermón Moncada"

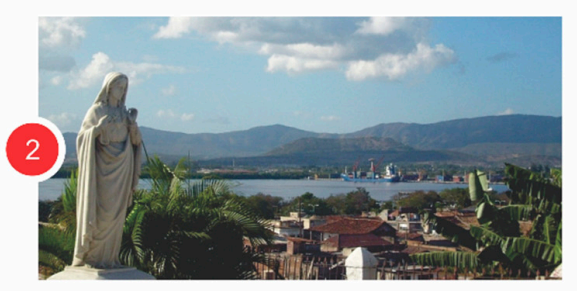

Church " Los desamparados"

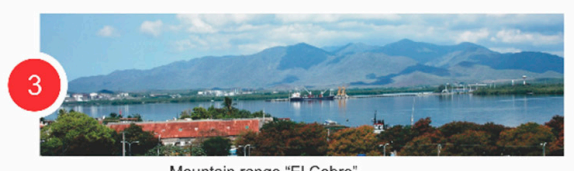

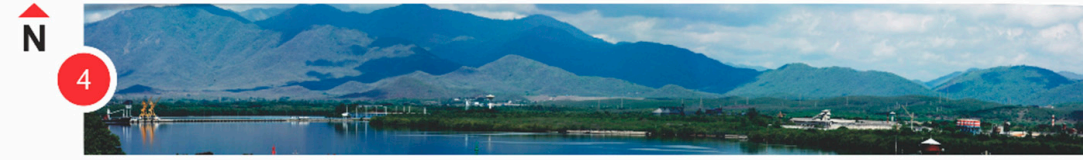

Wetland "San Miguel de Parada" and Mountain range "El Cobre" behind.

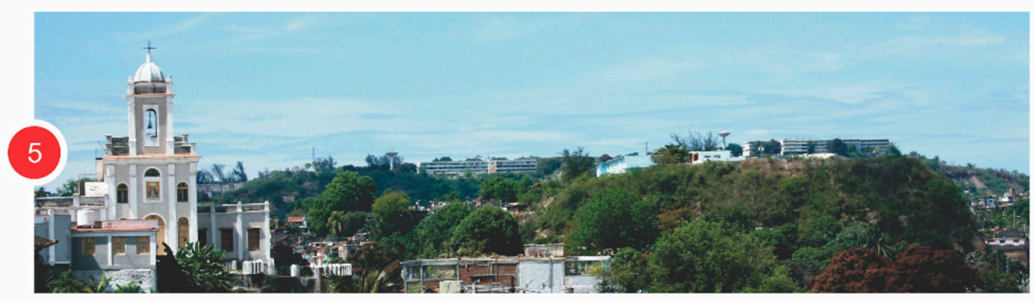

Church "Los desamparados" and Plateaus "El Fuerte" and "El Queque"

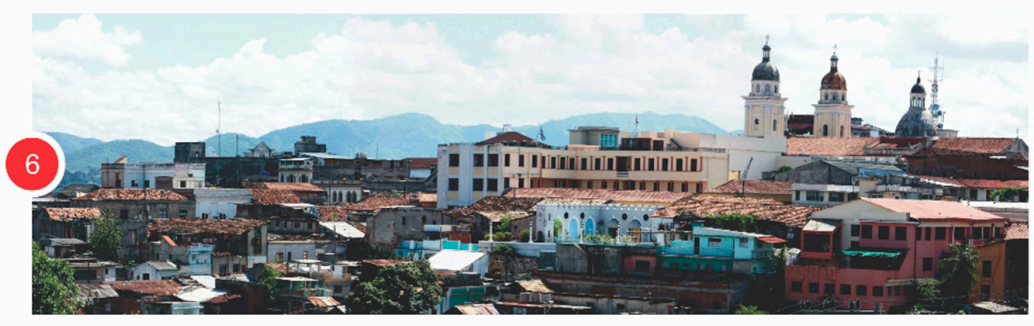

Behind towers of the Cathedral

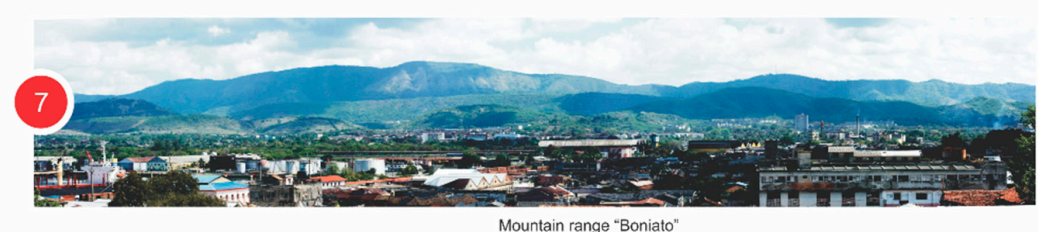

Mountain range "Boniato"

Figure 8. Visuals from neighborhood "El Tivoli".

Delimitation of landscapes of the visual gap from the Bay into landscape scopes and landscape units yielded the following: five landscape scopes, classified as A-B-C-D-E (Figure 9), eight landscape units of First, Order (Figure 10) and 29 landscape units of Order (Figure 11). An outstanding characteristic is that the sea is only present at landscape scopes A and B; the other landscape scopes correspond to mountainous areas. Scope B has the most spatial and functional complexity since it corresponds to the urbanized areas of Santiago de Cuba. This is followed by scope A, which corresponds to the multifunctional zone at the entrance of Santiago Bay. Scopes C, D and E correspond to rural spaces, which present less anthropogenic activities and, thus, less spatial complexity than A and B. 


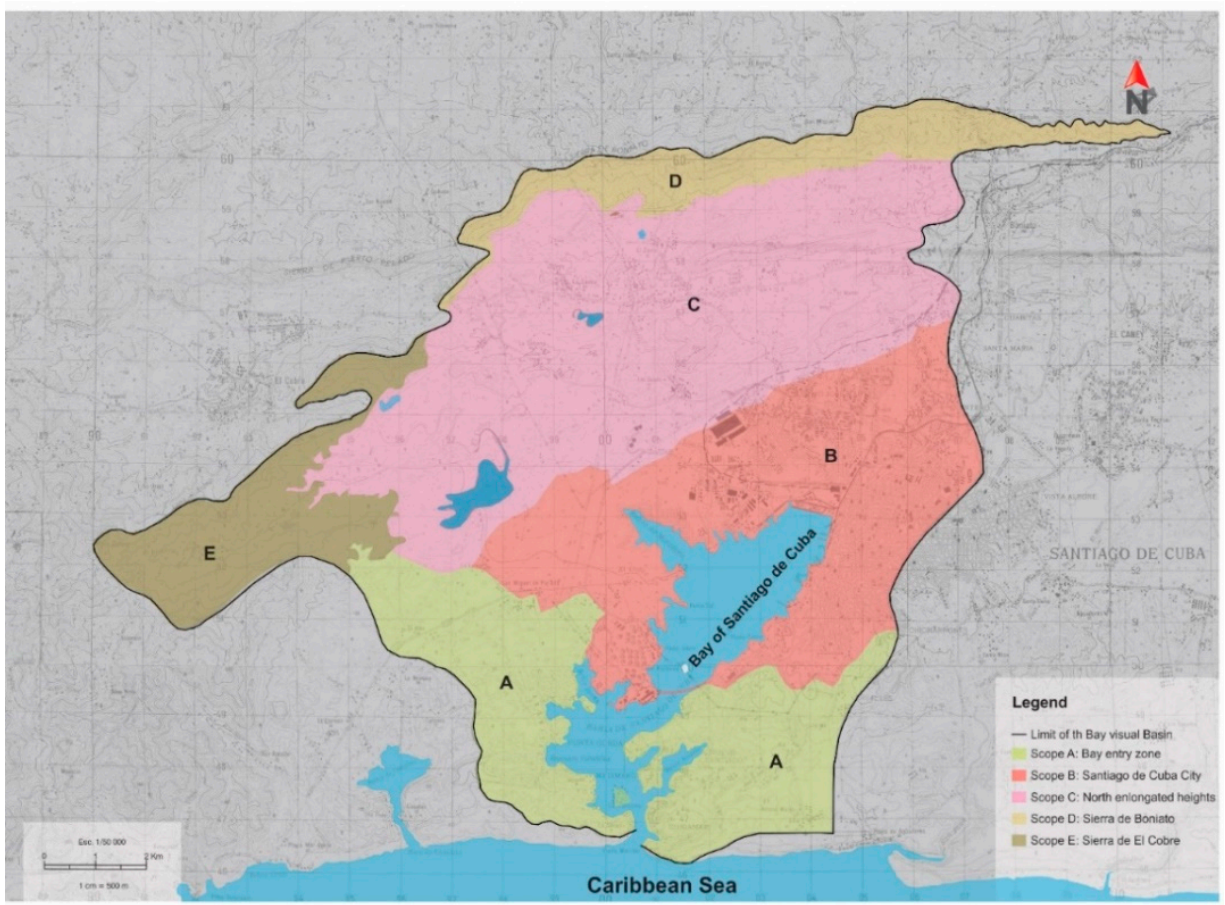

Figure 9. Delimitation of Landscape Scopes.

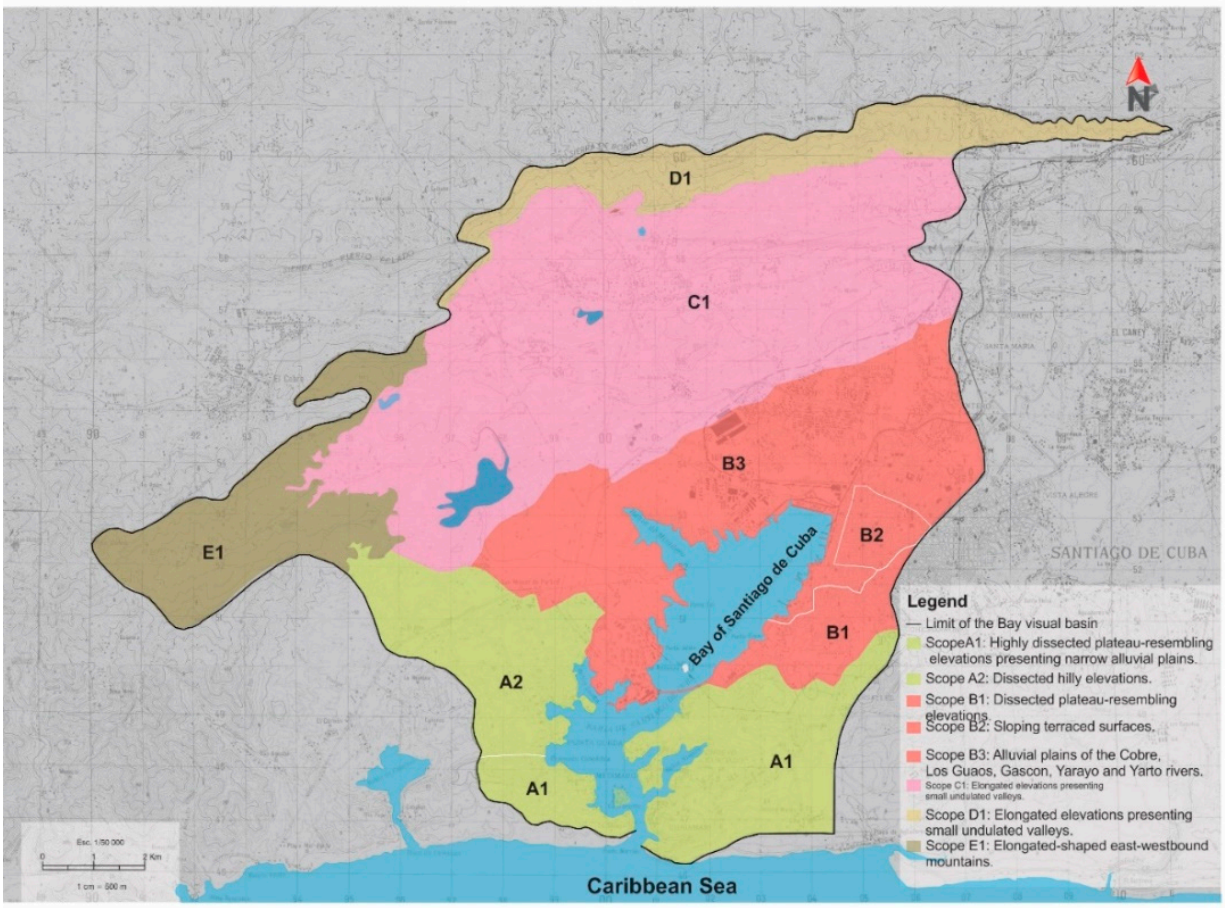

Figure 10. Delimitation of Landscape Units of First Order. 


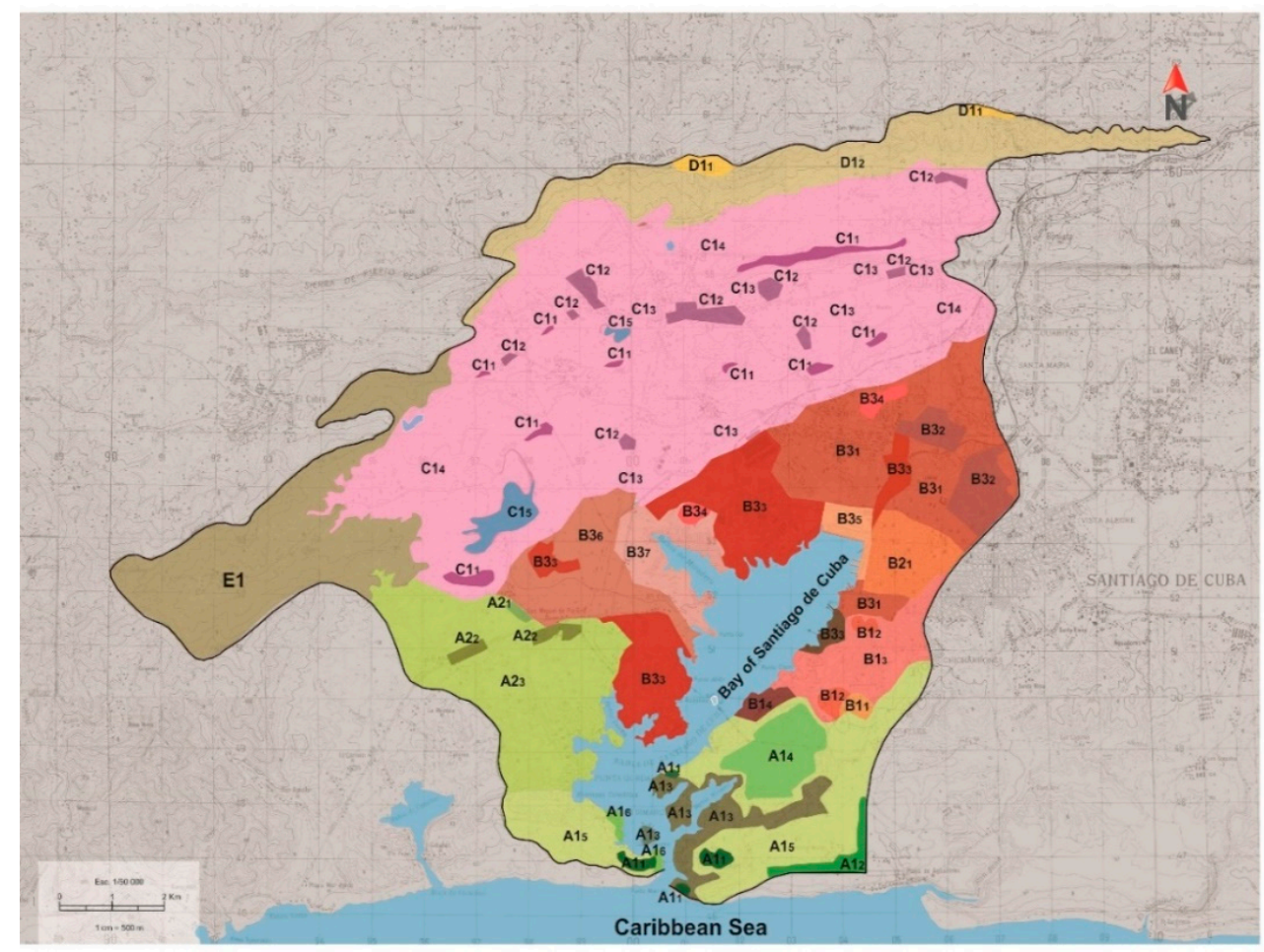

Figure 11. Delimitation of Landscape Units of Second Order.

The 29 landscape units included in the 5 landscape scopes were valued according to the scale proposed in three categories by the IMLA (Table 5), the process revealed the great differences between landscape units and landscape scopes. That is a consequence of the variety of functions present at landscapes of the visual gap due to the relief complexity and different kinds of spaces. Analysis of landscape unit valuation showed predominance of high scenic values due to the amphitheater characteristics of the visual gap, which enabled multiple scenes from different positions. Medium natural and cultural values predominated, as did high and medium historical values.

A and B, entrance to the Bay and Santiago de Cuba city respectively, were the scopes with higher values, followed by mountainous scopes. Those with plateaus had lowest values. Analysis of the 29 landscape units resulted in 7 Units with Category I (representing 24\%), 15 Units with Category II (52\%) and 7 Units with Category III (24\%).

Medium and high values categories predominate at the entrance of the Bay and the city of Santiago de Cuba. Categories of medium value predominate at mountainous scopes, while categories of low and medium values predominate at scopes with plateaus. Valuation of landscape units and scopes resulted in defining the general landscape values (Table 6). 
Table 5. Valuation of Landscape Units of Second Order.

\begin{tabular}{|c|c|c|c|c|c|c|c|c|c|c|c|c|c|c|c|c|c|c|c|c|c|c|c|}
\hline \multirow{2}{*}{ Scopes } & \multirow{2}{*}{ Units of First, Order } & \multirow{2}{*}{ Units of Second, Order } & \multicolumn{3}{|c|}{ Natural Value } & \multicolumn{3}{|c|}{ Cultural Value } & \multicolumn{3}{|c|}{ Historical Value } & \multicolumn{3}{|c|}{ Social Value } & \multicolumn{3}{|c|}{ Scenic Value } & \multicolumn{3}{|c|}{ Total } & \multicolumn{3}{|c|}{ Categories } \\
\hline & & & $\mathbf{H}$ & $\mathbf{M}$ & $\mathbf{L}$ & $\mathbf{H}$ & $\mathbf{M}$ & $\mathbf{L}$ & $\mathrm{H}$ & $\mathbf{M}$ & $\mathbf{L}$ & $\mathbf{H}$ & $\mathbf{M}$ & $\mathbf{L}$ & $\mathbf{H}$ & $\mathbf{M}$ & $\mathbf{L}$ & $\mathbf{H}$ & $\mathbf{M}$ & $\mathbf{L}$ & $\mathbf{H}$ & $\mathbf{M}$ & $\mathbf{L}$ \\
\hline \multirow{8}{*}{$\mathrm{A}$} & \multirow{6}{*}{$\mathrm{A} 1$} & A11 & & & & & & & & & & & & & & & & 4 & 1 & & & & \\
\hline & & $\mathrm{A} 12$ & & & & & & & & & & & & & & & 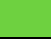 & 2 & 2 & 1 & & & \\
\hline & & $\mathrm{A} 13$ & & & & & & & & & & & & & & & & 4 & 1 & & & & \\
\hline & & A14 & & & & & & & & & & & & & & & & 2 & & 3 & & & \\
\hline & & A15 & & & & & & & & & & & & & & & & 2 & 2 & 1 & & & \\
\hline & & A16 & & & & & & & & & & & & & & & & 3 & 2 & & & & \\
\hline & \multirow{2}{*}{$\mathrm{A} 2$} & $\mathrm{~A} 21$ & & & & & & & & & & & & & & & & 1 & 2 & 2 & . & & \\
\hline & & $\mathrm{A} 23$ & & & & & & & & & & & & & & & & 2 & 3 & & & & \\
\hline \multirow{11}{*}{ B } & \multirow{4}{*}{ B1 } & B11 & & & & & & & & & & & & & & & & 2 & 3 & & & & \\
\hline & & B12 & & & & & & & & & & & & & & & & 2 & 3 & & & & \\
\hline & & B13 & & & & & & & & & & & & & & & & 1 & 4 & & & & \\
\hline & & B14 & & & & & & & & & & & & & & & & 1 & 1 & 3 & & & \\
\hline & B2 & B21 & & & & & & & & & & & & & & & & 4 & 1 & & & & \\
\hline & \multirow{6}{*}{ B3 } & B31 & & & & & & & & & & & & & & & & & 5 & & & & \\
\hline & & B32 & & & & & & & & & & & & & & & & 3 & 2 & & & & \\
\hline & & $\mathrm{B} 33$ & & & & & & & & & & & & & & & & 1 & 2 & 2 & & & \\
\hline & & B35 & & & & & & & & & & & & & & & & 2 & 2 & 1 & & & \\
\hline & & B36 & & & & & & & & & & & & & & & & & 4 & 1 & & & \\
\hline & & B37 & & & & & & & & & & & & & & & & 3 & 1 & 1 & & & \\
\hline \multirow{5}{*}{ C } & \multirow{5}{*}{$\mathrm{C} 1$} & C11 & & & & & & & & & & & & & & & & 1 & 2 & 2 & & & \\
\hline & & $\mathrm{C} 12$ & & & & & & & & & & & & & & & & & 2 & 3 & & & \\
\hline & & $\mathrm{C} 13$ & & & & & & & & & & & & & & & & & & 5 & & & \\
\hline & & C14 & & & & & & & & & & & & & & & & 1 & 3 & 1 & & & \\
\hline & & $\mathrm{C} 15$ & & & & & & & & & & & & & & & & & 1 & 4 & & & \\
\hline \multirow{2}{*}{$\mathrm{D}$} & \multirow{2}{*}{ D1 } & D11 & & & & & & & & & & & & & & & & 3 & 2 & & & & \\
\hline & & D12 & & & & & & & & & & & & & & & & 2 & 1 & 2 & & & \\
\hline $\mathrm{E}$ & E1 & E11 & & & & & & & & & & & & & & & & 2 & 1 & 2 & & & \\
\hline & Sub- & & 4 & 17 & 8 & 6 & 14 & 9 & 10 & 10 & 9 & 9 & 9 & 11 & 20 & 3 & 6 & 49 & 53 & 43 & 7 & 15 & 7 \\
\hline & TOT & & & 29 & & & 29 & & & 29 & & & 29 & & & 29 & & & 145 & & & 29 & \\
\hline & & & High & & & & & & Mediu & & & & & & Low & & & & & & & & \\
\hline
\end{tabular}


Table 6. General Landscape Values of Visual Gap from Santiago de Cuba City.

\begin{tabular}{|c|c|}
\hline Type of Value & Criteria \\
\hline Natural value & $\begin{array}{l}\text { - Strong presence of natural elements visually impacting the scenic landscape, such as relief, } \\
\text { irregular bay, vegetation, fauna and climate. } \\
\text { - Diversity of species present in vegetation and fauna. } \\
\text { - Presence of important ecosystems such as: mangroves, beaches and the protected area of San } \\
\text { Miguel de Parada Wetland. }\end{array}$ \\
\hline Cultural value & $\begin{array}{l}\text { - Presence of tangible landmarks of different cultures influencing the landscape context and } \\
\text { leaving remarkable and representative physical evidence of every stage of historical evolution. } \\
\text { Remarkable process of urbanization of Santiago de Cuba city, leading to residential, industrial, } \\
\text { touristic, agricultural and forest areas, as well as a presence of a dense network of } \\
\text { infrastructures having good connectivity among them. } \\
\text { Development of international nautical and cultural activities; Ex. Festival of the Caribbean } \\
\text { Culture, Sub-aquatic National Heritage. }\end{array}$ \\
\hline Historical value & $\begin{array}{l}\text { - Occurrence of international, national and local significant facts regarding politics, culture, } \\
\text { religion, production, army and society. } \\
\text { Relevant battles marking the rise and development of Santiago de Cuba city, for example: the } \\
\text { Spanish Cuban American War and the entire revolutionary process from the colonial era to the } \\
\text { definitive independence in } 1959 .\end{array}$ \\
\hline Social value & $\begin{array}{l}\text { Recognition of numerous sites with good landscape views frequently used by population for } \\
\text { pleasure, leisure, rest, observation, education, health, sports. }\end{array}$ \\
\hline Scenic value & $\begin{array}{l}\text { - Landscape with a great diversity of scenes from different observation points, with large } \\
\text { panoramic visuals, polychromy and sharp contrasts. } \\
\text { - } \quad \text { Presence of water bodies with remarkable reflections. } \\
\text { - } \quad \text { Continuous and precise edges and numerous landmarks at the bay. } \\
\text { Scenic backdrop in relief of high mountains and contrast with the Caribbean Sea. }\end{array}$ \\
\hline
\end{tabular}

Enhancing the cultural value requires improving the quality of constructions at the first coastline of Santiago de Cuba city, mainly of houses and industrial buildings. Improving the scenic value means establishing more points of observation and opening the city to waterfront. Note that such recommendations facilitate desired synergisms because preserving the natural landscape and improving the appearance of existing buildings will enhance the scenic value. Implementation of these recommendations requires the establishment of a legal framework of landscape regulations and a corresponding management authority to put them into practice.

The following additional actions regarding value categories of landscape units and scopes are recommended: preservation and integrated protection of landscapes that have special values per Category I; preservation with modifications, as well as rehabilitation and remodeling to recover affected or lost values in the units with landscapes scored in Categories II and III.

Finally, recommendations are proposed for the value management of the landscape of Santiago de Cuba Bay (level 4 of the method IMLA). These are described for each of the three factors considered by IMLA (natural, cultural and scenic factors), Table 7.

The new IMLA considers land use patterns and landform as important sources of information that contribute to the formation of landscape perceptions and values [37]. The most significant recommendations for value management of the natural landscape focus on preserving the relief characteristics and the irregular shape of the Santiago de Cuba Bay, as well as on preserving and improving vegetation and current land-uses. 
Table 7. Recommendations for the value management of the landscape of Santiago de Cuba Bay.

Natural Factors $\quad$ Cultural Factors $\quad$ Scenics Factors

- $\quad$ To preserve the natural characteristics of the bay and maintain the irregularity of its perimeter. Do not allow anthropogenic actions that modify the natural relief.

- $\quad$ To carry out actions to minimize the contamination of the bay's water bodies, as well as the natural characteristics of its coastal vegetation

- To take steps to protect the scenic importance of the basins of the rivers: "El Cobre", "Los Guaos" and "Gascón", developing actions with the provincial delegation of the Ministry of Science, Technology and Environment.

- $\quad$ To conserve and improve the existing natural forest formations in the basin, associated with the coastline of the bay, where mangrove forests, coastal xeromorphic scrub and swamp grassland predominate.

- To reforest degraded areas, such as the mining reserve "La Chivera".

- To carry out a reforestation program with native vegetation of the Basin with wood and fruit trees.

- To eliminate fast-growing, non-native plant species, recently introduced and intended for energy purposes such as Ipil Ipil (Leucaena Leuco-cephala) and Marabú (Dichrostachys cinerea).

- To carry out the environmental sanitation of the mangrove swamp in "Ensenada de Miradero."

- $\quad$ To eliminate waste and solid waste dumping in "Ensenada del Miradero."

- $\quad$ To establish a regulatory framework to punish actions such as logging and poaching, the extraction of soils from nearby quarries, the unauthorized access of people to the mangrove and the introduction of non-native species.
- To improve the state of residential buildings located on the first coastline of the city of Santiago de Cuba. Emphasize roof solutions, which must be adapted to the typological characteristics of the context.

- To carry out maintenance actions for buildings constituting landmarks in the landscape.

- To recover the residential wooden buildings in the "El Tivoli" neighbourhood. Establish constructive regulations on the height, location and altitude of the new constructions, so that they create harmonious relationships with the context of the setting.

- To recover disused warehouses in the coastal zone for use with public functions related to the sea.

- $\quad$ Remodel warehouses in the port area. To promote improvements in structures associated with warehouses, the thermo-electric plant, the refinery, the mill, the cement factory, the shipyard and the Guillermón Moncada port warehouses).

- To carry out actions to remove dirt, stains, inadequate coatings and lack of paint that produce a negative visual impact on the landscape.

- To convert the industrial environment of the cement factory to a space for public functions with a direct link to the bay.

- Rehabilitate the tourist road as a significant way to contemplate the landscape, rescuing the multiple viewpoints that it offers.

- To establish framework for the regulation and control of the interventions carried out on the landscape of the Bay's basin.

- $\quad$ To create a specialized multi-disciplinary group that puts into practice the regulatory framework and contributes to the decision-making regarding the actions carried out around the Bay.
- Maintain the polychromy of the landscape and the contrasts in the built elements, using red, yellow and other colours. Maintain the diversity of shades/brightness.

- Use appropriate materials in terms of colour, shape and texture for the formal and technical-constructive solutions of the buildings, especially in areas of heritage value such as the Historic Urban Center and the neighborhoods of the entrance of the Bay.

- To take advantage of the higher elevations with better vistas for the location of public functions, promoting

adequate accessibility.

- $\quad$ The highest and most visible areas should not be compromised with private functions or restrictions of access.

- To redesign the waterfront in Santiago to open the city to the sea. To build an urban waterfront with adequate equipment to enhance the enjoyment of the landscape of the northern area of the bay.

- $\quad$ To develop landscape observation points from the west of the Bay and made accessible with good trails and roads.

- $\quad$ To restore the ferry service that transports passengers through the bay, from the north to the bay entrance.

- To create a network of viewpoints with public accessibility for landscape observation activity. They have to be located on the east coast and must be equipped with adequately.

- $\quad$ To connect this network of viewpoints with the main roads of the city of Santiago de Cuba and hiking trails.

\section{Discussion}

\subsection{Key Observations about the Landscaping Approach}

The conceptual complexity and diversity of "landscape" can be summarized as a set of socio-ecological relations that result in a visual manifestation; an approach taken into account herein. The literature review (Table 1) shows that consensus on landscape values exists only for a few propositions, such as the importance of the aesthetic value in eight proposals, natural and cultural in seven and natural and historical and environmental with six and five respectively. Divergences are more frequent in economic, ethnologic, territorial, religious and biological values and may derive from the diversity of disciplinary backgrounds of the authors. The lack of unity illustrates the importance and the originality of considering the integrated characterization and valuation of landscape (IMLA) for sustainable management. Therefore, this research considers the integrated landscape approach [76] as a way to understand and manage the environment in accordance with the United Nation's Sustainable Development Goals (SDGs).

Analyzing landscape approaches also showed the stark difference between landscape and image. Landscape represents a marked physical character $[5,20,21]$ while image refers 
to a clear conceptual nature, centralizing complex interactions and relationships among people and their environment [14,77]. In this research, landscape was considered as a visible manifestation and not as a mental representation leading to psycho-perceptual valuation.

Different epistemological approaches can be used to study landscape. At present, there is a marked tendency to interrelate and articulate diverse aspects for integrated landscape analysis [8,78]. The approach used in this research (IMLA) to characterize and assess landscape for value management is based on three essential ideas:

(1) Landscape is a phenomenon historically conditioned by a culture $[48,77]$. Landscape can be understood as a process in continuous evolution due to the different societies and corresponding histories, where all cultural aspects are involved; wherefore landscape constitutes a reflection of the historical development of human society, showing the ways of life in a given territory according to human appropriation and exploitation.

(2) The whole territory and the elements interrelated thereto, constitute the landscape [14, 79]. In this case, (i) the whole space is analyzed from the physical-geographical point of view and (ii) all its elements are analyzed in order to group them into two main systems: the natural elements, including biotic and abiotic components; and the cultural elements, derived from human actions and their relationships.

(3) Landscape is a scene thus, it can be observed [80,81]. Landscape is analyzed by the observer from a specific position or several ones, since landscape is conceived as an object of contemplation, which involves seeing or observing.

\subsection{Lessons Derived from IMLA}

Visual landscape quality assessment refers to the methodological proposal used to describe and evaluate the scenic beauty of landscapes [43].

Analysis of various methodologies showed diversity of variables used to understand landscapes how each technique is shaped by the study area. Previous methodological experiences and studies about landscape were considered for the method proposed herein [13,23,25-29,37,49,82-84]. Landscape was classified according to its values. However, IMLA can be contrasted with other approaches [44]. IMLA facilitates the inclusion of a sensitivity index that accounts for the interaction of o natural processes and human pressure.

Landscape valuation derived from consideration of historical-social processes responsible for the current landscape configuration, rejecting a subjective approach [85].

A diversity of approaches employing visual-aesthetic values for policy scenarios appear in the literature [86]. Other include aesthetic and ecological values [87,88], or interviews with a qualitative approach and visual data to explore landscape values IMLA employed a formal approach rooted in theoretical-considerations to define the landscape. Critical analysis of the different methodologies led to determining the system of factors, variables and sub-variables used for the integrated characterization and valuation of the subject of study. IMLA incorporated the various points of view expressed by different specialists in the surveys and expert committees created to discuss landscape values.

The stage of landscape characterization led to establishing the specific characteristics and delimitation of the subject of study, as well as analysis of its social-historical conditions. Landscape characterization originated from the examination of the most general elements of the system, i.e., natural, cultural and scenic factors. We determined and summarized essential features of the landscape, its scopes and landscape units following an evaluativeanalytical process. Experiences derived from landscape and on-site valuation carried out by different authors offered the starting point for level three of the method. Additionally, we considered previous characterizations of the subject of study. Values assigned to landscape and an associated qualitative scale facilitated determination of the different value categories. 
The new IMLA considers the potential range of values associated with each landscape unit and facilitates effective landscape management. "Landscape assessment constitutes a bridge between scientific knowledge and socio-economic issues that are needed to meet the demands of sustainable landscape planning and management" [89]. Moreover, landscape analysis will help regional authorities plan and find a consensus for multiple societal needs and demands $[90,91]$. This is critical to resolving land use conflicts to achieve sustainable development [92].

These landscape units have been historically threatened by natural events associated with forest fires, the rise in mean sea level due to climate change and impact of hurricanes and related strong winds, coastal flooding and erosion processes. There are other threats of anthropic origin that also put in danger landscape units investigated in this paper, e.g., pollution linked to atmospheric contamination, discharge of solid waste materials and wastewaters from urban activities, deforestation, poaching, etc.

IMLA facilitates continuous systematic landscape reevaluation. This is required for safeguarding of landscape values and the work to recover degraded landscapes and those in danger of disappearing. IMLA requires a multidisciplinary team to incorporate the cultural, social and environmental aspects into management recommendations. Furthermore, effective implementation means using adaptive management that responds to planning, designing and assessment at multiple scales [93,94]. IMLA requires continuous feedback from all stakeholders.

\subsection{Validation of IMLA in the Study Site}

The landscape visual gap of Santiago de Cuba Bay constitutes a cultural landscape with a high anthropization level indicative of the quick urban development following the founding of the city $[60,95]$. Validation of IMLA defined the evolutive stages demarked by major incidences of landscape transformations. The IMLA enables landscape planning that considers the complexity of relevant features rather than single components and objects of protection in isolation [89]. IMLA responds to the problem of confusion created by attempting to incorporate too many variables absent of a systematic approach [15,30-34].

Examining the different landscape components when validating the proposed system of factors, variables and sub-variables, resulted in recognizing the natural, cultural and scenic characteristics of the visual gap. The irregular relief, the water-mirror surface of the bay and the diversity in vegetation predominate among the natural landscape's components. Fauna, except for birds and rolling rivers at the visual gap, is not a significant natural landscape component in this method. IMLA is consistent with the proposals of many authors [96-98]. A group of authors analyzed the diversity of natural landscapes measuring specific aspects such as natural heritage sites and natural viewpoints [28,53,99-101]. Others used natural indicators, such as the diversity of relief, watercourses, coastal lagoons, estuaries and beaches [26,44,102-104]. In this application of IMLA, we did not consider noise pollution, but it certainly could be included in future analysis.

The urbanization of Santiago de Cuba city, with large residential areas and industrial zones, imbedded in an outstanding landscape of the visual gap, predominates among the cultural components. Furthermore, agro-systems influence the landscape by altering the vegetation $[59,72]$.

The visual components are the most significant among the scenic factors, due to the contrast in colors, shapes, textures and lines of landscape [14], although spatial features are also significant because of the great number of landmarks, especially the man-built ones.

The most relevant physical components are relief, human actions and presence of water, vegetation and scenic background. In general, the validation proved the effectiveness of the method for landscape characterization, valuation and value management.

As discussed above and shown in Table 4 and Appendix D, a range of high, medium and low values for Landscape Units were identified in Santiago de Cuba Bay. The case study revealed that as in the [48] research, values were not limited to the physical forms of landscapes units, but also related to contemporary or anthropic past practices. Validating 
the method at Santiago de Cuba Bay establishes the usefulness of this tool for decisionmaking processes about value protection at cultural landscapes.

Landscape scientists will find IMLA useful in addressing the loss of identity and cultural heritage $[99,100]$. The method contributes to the implementation of the UNESCO Cultural Heritage Protection Act [105] that, in the study area, has one example declared as Cultural Heritage of Humanity: The Castle San Pedro de la Roca [106]. Due to its historical and landscape values that need to be protected, the castle was the object of a comprehensive rehabilitation project in recent years [107].

Such researchers are conscious of the benefits that coastal ecosystems like estuarine, lagoons and mountain bay have provided to local populations. These landscapes are an excellent example of the interdependence between nature and man. IMLA analyzed a cultural landscape resistant to changing natural, cultural and scenic factors. It generated recommendations to be tested in Santiago de Cuba Bay for improving the resilience of a landscape long affected by human activity. Our proposal is compatible with other studies of coastal landscapes recently carried out in Cuba [108,109].

IMLA assumes the sustainable landscape approach [110], determining that, for sustainable management of landscape, citizen participation must be granted. Communities, together with the government and decision-makers, can manage the natural capital of the area and the wide range of uses, to reduce anthropogenic impacts and improve long-term human well-being in a changing world.

\section{Conclusions}

Critically assessing several methods for landscape analysis led to the establishment of a system of natural, cultural and scenic factors, as well as of variables and sub-variables for an integrated characterization and valuation of landscape from the adopted holistic approach. IMLA structure includes four levels of analysis:

(1) Definition of the landscape to be analyzed;

(2) Landscape characterization, including analysis of the historical-social conditions and delimitation into landscape scopes and landscape units;

(3) Landscape valuation; and

(4) Landscape value management; the last stage of the whole process where recommendations for landscape re-valuation are provided.

The method is systematic and includes both inductive and deductive reasoning. For the analysis, the parts and components of the method were classified into sub-systems. Its articulation is represented in the conjunction and overlapping of all factors and variables proposed.

Five historical evolutive stages of the visual gap from Santiago de Cuba Bay were identified when validating the method:

(a) Pre-foundation stage;

(b) Formation of urban nucleus;

(c) Consolidation;

(d) Urban and rural expansion;

(e) Industrialization.

Essential features of landscape of the visual gap from Santiago de Cuba Bay were also determined after validation. In addition, the spatial configuration of the visual gap was delimitated into five landscape scopes, eight first order landscape units and 29 second order landscape units. According to their values, these last 29 units were classified into: seven high value units, 15 medium value units and seven low value units. Therefore, medium value units were predominant. The landscape scope units with higher values were $\mathrm{A}$ (entrance to the Bay area) and B (entrance to Santiago city). Furthermore, the scenic value is the most significant, since 20 of the 29 landscape units analyzed were classified with high values. The recommendations derived from validating the new IMLA at Santiago de Cuba 
Bay have great importance for landscape re-valuation. The validation also provided the possibility of using the method in other similar contexts.

Author Contributions: Conceptualization, C.B.M., E.C., L.R.; methodology, C.B.M., E.C., O.P.M., L.R., validation, C.B.M., E.C., S.Z., investigation, C.B.M., E.C., L.R.: resources, G.A., A.S.; writingoriginal draft preparation, C.B.M., A.S., O.P.M., G.A., B.C., writing-review and editing, C.B.M., S.Z., G.A., S.Z., B.C.; supervision, C.B.M., G.A.; project administration, C.B.M. All authors have read and agreed to the published version of the manuscript.

Funding: This research was funded by project INDEX No. INV.1106-01-007-12, titled "Resilient cities: minimizing vulnerabilities when facing extreme meteorological phenomena and climate changes at coastal communities", Universidad de la Costa, Colombia and by the Cuban Project "Adaptive Governance for the coastal and marine planning in Cuba", Universidad de Oriente, Cuba.

Informed Consent Statement: The study did not involve humans or animals.

Data Availability Statement: Data supporting reported results can be found asking directly of the second author.

Acknowledgments: This work is a contribution to Project INDEX No. INV.1106-01-007-12, named "Resilient cities: minimizing vulnerabilities when facing extreme meteorological phenomena and climate changes at coastal communities", Universidad de la Costa, Colombia, as well as to the Cuban Project "Adaptive Governance for the coastal and marine planning in Cuba", Universidad de Oriente, Cuba and to the PAI Research Group RNM-328 of Andalucía (Spain). Some authors want to acknowledge the PROPLAYAS Network because some of them are members.

Conflicts of Interest: The authors declare no conflict of interest.

\section{Appendix A. Synthesis of System of Factors, Variables and Sub-Variables for Landscape Characterization. (Level 2 and Phase 3 of Method IMLA)}

Table A1. Synthesis of Natural Factors, Variables and Sub-Variables for Landscape Characterization.

\begin{tabular}{|c|c|c|}
\hline Factors & Variables & Sub-Variables \\
\hline \multirow{5}{*}{ NATURAL } & $\begin{array}{l}\text { Relief and Altimetry }[4,10,42] \\
\text { - } \quad \text { Plains } \\
\text { - } \quad \text { Hills } \\
\text { - } \quad \text { Terraces } \\
\text { - } \quad \text { Plateaus } \\
\text { - } \quad \text { Mountains } \\
\text { - } \quad \text { Heights and valleys }\end{array}$ & $\begin{array}{l}\text { - Shape: hilly, mountainous, flat, terraced, plateaued [13] } \\
\text { - } \quad \text { Localization: edge and central. } \\
\text { - } \quad \text { Extension: in square kilometers. } \\
\text { - } \quad \text { Altitude: low (up to } 100 \text { m), medium (100-500 m), high } \\
\text { (over } 500 \text { m) } \\
\text { - Orientation: N-S, E-W, NW-SE, NE-SW. } \\
\text { - Oronyms: saws, picks, heights, hills, mountain passes, } \\
\text { valleys. }\end{array}$ \\
\hline & $\begin{array}{l}\text { Hydrography }[7,10,42,53] \\
\text { - } \quad \text { Rivers } \\
\text { - } \quad \text { Water bodies }\end{array}$ & $\begin{array}{l}\text { - } \quad \text { Extension: in square or linear kilometers. } \\
\text { - } \quad \text { Orientation: N-S, E-W, NW-SE, NE-SW. } \\
\text { - } \quad \text { Type of river: permanent or intermittent. }\end{array}$ \\
\hline & $\begin{array}{l}\text { Vegetation }[4,7,10] \\
\text { Natural } \\
\text { - } \quad \text { Secondary } \\
\text { - } \quad \text { Cultural }\end{array}$ & $\begin{array}{l}\text { - } \quad \text { Species: arboreous, bush-like and herbaceous. } \\
\text { - } \quad \text { Color: white, green, light green, dark green, dull red }[13,21] \\
\text { - } \quad \text { Height: } \mathrm{h} / 2 \mathrm{~m} \text { (herbaceous), } 2-6 \mathrm{~m} \text { (bush-like) } 6-15 \mathrm{~m} \text { and } \\
\text { 15-25 m (arboreous) } \\
\text { - } \quad \text { Foliage continuance: perennifolium and caducifolium. } \\
\text { - } \quad \text { State: good, regular and bad. } \\
\text { - } \quad \text { Type of soil on which it is developed. }\end{array}$ \\
\hline & Fauna $[4,7,20,21]$ & $\begin{array}{ll}\text { - } & \text { Species } \\
\text { - } & \text { Localization }\end{array}$ \\
\hline & $\begin{array}{l}\text { Weather }[5,6,20] \\
\text { Temperature } \\
\text { - } \quad \text { Rainfall, Winds, Clouds, Sunning }\end{array}$ & - $\quad$ Maximum, minimum and medium values. \\
\hline
\end{tabular}


Table A2. Synthesis of Cultural Factors, Variables and Sub-Variables for Landscape Characterization.

\begin{tabular}{|c|c|c|}
\hline Factors & Variables & Sub-Variables \\
\hline \multirow{6}{*}{ CULTURAL } & $\begin{array}{l}\text { Urbanization }[4,13,42,55,102] \\
\text { Zones for: Dwelling } \\
\text { Industries } \\
\text { Facilities of different services } \\
\text { Transportation } \\
\text { Tourism }\end{array}$ & $\begin{array}{l}\text { - } \quad \text { Extension: in square kilometers. } \\
\text { - } \quad \text { Scale: human or monumental. } \\
\text { - } \quad \text { Spatial organization: woof, grouped, scattered, linear, radial and central. } \\
\text { - } \quad \text { Apparent state: good, regular and bad. } \\
\text { - Visual relation to the landscape: existing or non-existing. }\end{array}$ \\
\hline & Concentrated rural settlements & $\begin{array}{l}\text { Extension: in square kilometers. } \\
\text { - } \quad \text { Scale: human or monumental. } \\
\text { - } \quad \text { Spatial organization: woof, grouped, scattered, linear, radial and central. } \\
\text { - } \quad \text { Apparent state: good, regular and bad. } \\
\text { - Visual relation to the landscape: existing or non-existing. }\end{array}$ \\
\hline & $\begin{array}{l}\text { Agricultural systems }[4,14] \\
\text { Agricultural } \\
\quad \text { Forestal }\end{array}$ & $\begin{array}{l}\text { - } \quad \text { Extension: in square kilometers. } \\
\text { - } \quad \text { Spatial organization: woof, grouped, scattered, linear, radial and central. } \\
\text { Existing constructions: dwellings, agricultural facilities and others. }\end{array}$ \\
\hline & $\begin{array}{l}\text { Mining systems }[4,21,55,97,98] \\
\text { - } \quad \text { Mining zones }\end{array}$ & $\begin{array}{l}\text { - } \quad \text { Extension: in square kilometers. } \\
\text { - Spatial organization: woof, grouped, scattered, linear, radial and central. }\end{array}$ \\
\hline & $\begin{array}{l}\text { Infrastructure Facilities for: } \\
\text { - Transportation } \\
\text { - } \quad \text { Electricity } \\
\text { - Water Reservoirs and Channels } \\
\text { - } \quad \text { Bridges and Factories. }\end{array}$ & $\begin{array}{l}\text { Extension: square and linear kilometers. } \\
\text { - } \quad \text { Scale: human or monumental. } \\
\text { - Apparent state: good, regular and bad. }\end{array}$ \\
\hline & $\begin{array}{l}\text { Pollution }[25,79] \\
\text { Land } \\
\text { - Air } \\
\text { - Water }\end{array}$ & $\begin{array}{l}\text { - Pollutant elements } \\
\text { - } \quad \text { Causative Effects }\end{array}$ \\
\hline
\end{tabular}

Table A3. Synthesis of Scenic Factors, Variables and Sub-Variables for Landscape Characterization.

\begin{tabular}{|c|c|c|c|}
\hline Factors & Variables & & Sub-Variables \\
\hline \multirow{5}{*}{ SCENIC } & Visual Gap & ! & $\begin{array}{l}\text { Size: large (more than } 70 \% \text { of the total gap), average }(30-70 \% \text { of the total gap), small (less } \\
\text { than } 30 \% \text { of the total gap) } \\
\text { Shape: round, elongated and irregular. } \\
\text { Compactness: compact, or hollowed. }\end{array}$ \\
\hline & Visibility $[10,42]$ & $\begin{array}{l}\square \\
\square \\
\square \\
\square \\
\square \\
\square \\
\square \\
\square \\
\text { a }\end{array}$ & $\begin{array}{l}\text { Observer's position: upper, the same as observation point and lower. } \\
\text { Observation point altitude: low (0-20 msnm), average (20-60 msnm), high (60-100 msnm), } \\
\text { very high. } \\
\text { Visual gap opening: } 90^{\circ}, 180^{\circ}, 270^{\circ} \text { y } 360^{\circ} \\
\text { Distance: } \\
\text { 1st intraocular plane: less than } 500 \mathrm{~m} \\
\text { 2nd ocular plane: shallow depth: } 500-5000 \mathrm{~m} \\
\text { Average depth: } 500-2000 \mathrm{~m} \\
\text { High depth: } 2000-3500 \mathrm{~m} \\
\text { 3rd extraocular plane: more than } 5000 \mathrm{~m} \\
\text { Type of visual field: closed, focused, panoramic. } \\
\text { Intervisibility: high (more than } 50 \%) \text {, average }(25-50 \%), \text { low (less than } 25 \%)\end{array}$ \\
\hline & Visual components $[13,14]$ & $\begin{array}{l}\text { a } \\
\text { a } \\
\text { a }\end{array}$ & $\begin{array}{l}\text { Color: nuance or dye stuff, saturation or tone (light or dark) and brilliance (bright or matt) } \\
\text { Texture: grain (fine or thick), density (dense or scattered) } \\
\text { Shape: type (two-dimensional or three-dimensional), geometry (regular or irregular) } \\
\text { Line: definition (continued or discontinued), complexity (undulating, crooked, or straight), } \\
\text { orientation: (horizontal, vertical, or sloping) } \\
\text { Lighting: frontal, lateral and rear. }\end{array}$ \\
\hline & $\begin{array}{l}\text { Physical components } \\
{[4-6,10,14,20,21,42,99,100]}\end{array}$ & $\begin{array}{l}\mathbf{m} \\
\mathbf{\square} \\
\mathbf{\square} \\
\mathbf{\square}\end{array}$ & $\begin{array}{l}\text { Presence of water. } \\
\text { Relief. } \\
\text { Vegetation. } \\
\text { Human actions. } \\
\text { Scenic background. } \\
\text { Mobile forms. }\end{array}$ \\
\hline & Spatial components $[14,42,102]$ & 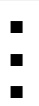 & $\begin{array}{l}\text { Milestones. } \\
\text { Surfaces or zones. } \\
\text { Edges. }\end{array}$ \\
\hline
\end{tabular}


Appendix B. Shape of the Visual Gap. (Source: Modified from Aguilo 1998)

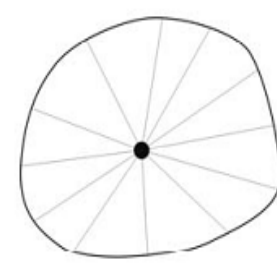

A: Circular

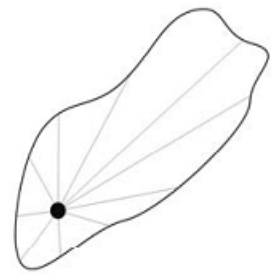

B: Elongated

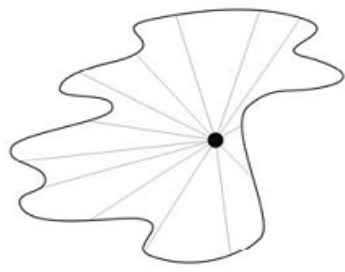

C: Irregular

Figure A1. Different landscape geometric forms of the visual gap. (A) Circular shaped landscapes; (B) elongated landscapes; (C) irregular shaped landscapes.

Appendix C. Compactness of the Visual Gap (Source: Modified from Aguilo 1998)

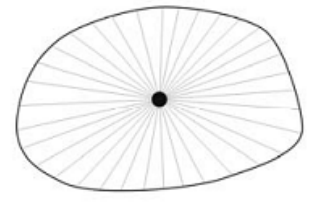

A: Compact

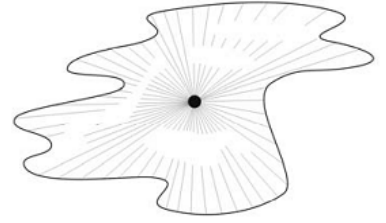

B: Hollowed

Figure A2. (A) Compact landscape of visual gap: means flat land, without obstacles, the content of the landscape completely visible. (B) Hollowed landscape of the visual gap: refers to rough land, with a great number of visible obstacles.

Appendix D. Position of the Observer (Source: Modified from Aguilo 1998)

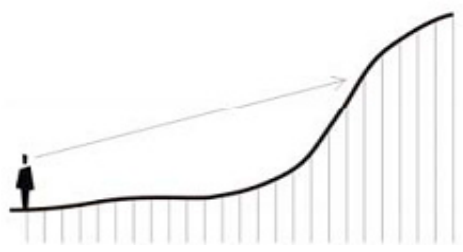

A: Lower level

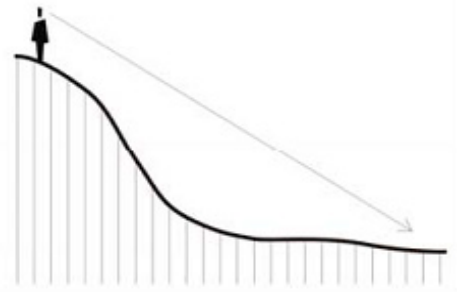

B: Upper level

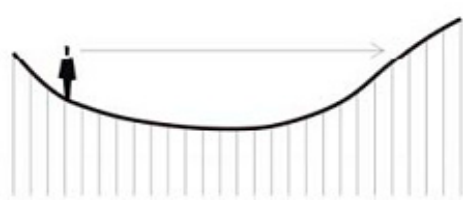

C: Same level

Figure A3. Differents observer's position to determine landscape's scope according to the visual aspects: (A) placed down from the landscape scenery; (B) placed up or (C) at the same level. The upper position expands the visual scope and provides better understanding about arrangement of landscape components.

The observer's position plays an outstanding role when analyzing visibility; for example: (A) placed down from the landscape scenery; (B) placed up or, (C) placed at the same level. The upper position expands the visual scope and provides better understanding about arrangement of landscape components. 


\section{Appendix E. Parameters of Valuation for Each Value}

Table A4. Scales of values high, medium and low by types of factors analyzed.

\begin{tabular}{|c|c|c|c|}
\hline Natural Value & High Value & Medium Value & Low Value \\
\hline \multirow{5}{*}{$\begin{array}{l}\text { Environmental } \\
\text { components: } \\
\text { mountainous relieves, } \\
\text { tablelands, hills, terraces, } \\
\text { cliffs and other } \\
\text { geographical accidents. } \\
\text { Hydrography: bays, } \\
\text { rivers, lakes, cascades, } \\
\text { wetlands. } \\
\text { Vegetation and Fauna: } \\
\text { diversity of plants with } \\
\text { different tones, natural } \\
\text { and secondary woods, } \\
\text { migratory birds, species } \\
\text { in danger of extinction. } \\
\text { Climate Conditions: } \\
\text { good visibility, } \\
\text { luminosity, air } \\
\text { transparency. }\end{array}$} & \multirow{2}{*}{$\begin{array}{l}\text { Presence of different } \\
\text { geographical accidents. }\end{array}$} & \multirow{2}{*}{$\begin{array}{l}\text { Geographical accidents with } \\
\text { some anthropic components. }\end{array}$} & $\begin{array}{l}\text { Geographical accidents not } \\
\text { visible }\end{array}$ \\
\hline & & & $\begin{array}{l}\text { or completely changed by } \\
\text { human anthropic activity. }\end{array}$ \\
\hline & $\begin{array}{l}\text { Rivers with cascades, } \\
\text { wetlands, polylobuled pocket } \\
\text { bays with irregular perimeter. }\end{array}$ & $\begin{array}{l}\text { Rivers of short course and low } \\
\text { volume, wetlands, pocket } \\
\text { bays without irregularities. }\end{array}$ & $\begin{array}{l}\text { No rivers, nor wetlands. Bays } \\
\text { without irregularities in their } \\
\text { perimeters. }\end{array}$ \\
\hline & $\begin{array}{l}\text { Biodiversity, presence of } \\
\text { endemic species and/or in } \\
\text { danger of extinction, } \\
\text { migratory birds, natural } \\
\text { vegetation, mainly woods in } \\
\text { advanced states. }\end{array}$ & $\begin{array}{l}\text { Biodiversity without endemic } \\
\text { species and/or migratory } \\
\text { birds or in danger of } \\
\text { extinction, secondary and } \\
\text { cultural vegetation in } \\
\text { intermediate states. }\end{array}$ & $\begin{array}{l}\text { No biodiversity, no endemic } \\
\text { species, no migratory birds or } \\
\text { in danger of extinction, } \\
\text { cultural and secondary } \\
\text { vegetation in early states. }\end{array}$ \\
\hline & $\begin{array}{l}\text { Climatic conditions with } \\
\text { visibility, air transparency, } \\
\text { luminosity. }\end{array}$ & $\begin{array}{l}\text { Climatic conditions with } \\
\text { medium visibility and low } \\
\text { luminosity due to air } \\
\text { transparency. }\end{array}$ & $\begin{array}{l}\text { Climatic conditions without } \\
\text { good visibility, air opacity and } \\
\text { low luminosity. }\end{array}$ \\
\hline Cultural Value & High Value & Medium Value & Low Value \\
\hline $\begin{array}{l}\text { Human prints in } \\
\text { landscape throughout } \\
\text { the years. }\end{array}$ & $\begin{array}{l}\text { Settlements with formal } \\
\text { quality and good harmony. }\end{array}$ & $\begin{array}{l}\text { Settlements with formal } \\
\text { quality, but with presence of } \\
\text { inharmonic or discordant } \\
\text { elements. }\end{array}$ & $\begin{array}{l}\text { Settlements without formal } \\
\text { quality and with inharmonic } \\
\text { or discordant elements. }\end{array}$ \\
\hline 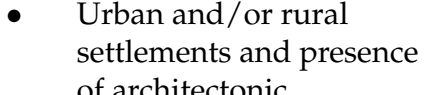 & $\begin{array}{l}\text { Components apparently well } \\
\text { preserved. }\end{array}$ & $\begin{array}{l}\text { Components apparently not } \\
\text { well preserved. }\end{array}$ & $\begin{array}{l}\text { Components apparently bad } \\
\text { preserved. }\end{array}$ \\
\hline $\begin{array}{l}\text { industrial, touristic, port } \\
\text { and airport complexes. } \\
\text { - Agro-systems related to }\end{array}$ & $\begin{array}{l}\text { Patrimonial and traditional } \\
\text { values with national and/or } \\
\text { international recognition. }\end{array}$ & $\begin{array}{l}\text { Patrimonial and traditional } \\
\text { values locally recognized. }\end{array}$ & $\begin{array}{l}\text { No patrimonial nor traditional } \\
\text { values. }\end{array}$ \\
\hline $\begin{array}{l}\text { agriculture, cattle, or } \\
\text { forest exploitation. } \\
\text { Infrastructures like }\end{array}$ & $\begin{array}{l}\text { Productive agro-systems } \\
\text { apparently with good } \\
\text { installations. }\end{array}$ & $\begin{array}{l}\text { Productive agro-systems } \\
\text { apparently with not good } \\
\text { installations. }\end{array}$ & No productive agro-systems. \\
\hline $\begin{array}{l}\text { roads, bridges, water } \\
\text { reservoirs, channels. }\end{array}$ & $\begin{array}{l}\text { Infrastructures apparently in } \\
\text { good state. }\end{array}$ & $\begin{array}{l}\text { Infrastructures apparently in } \\
\text { regular state. }\end{array}$ & $\begin{array}{l}\text { Infrastructures apparently in } \\
\text { bad state. }\end{array}$ \\
\hline Historic Value & High Value & Medium Value & Low Value \\
\hline
\end{tabular}

- $\quad$ Presence of outstanding events and personalities regarding to politics, culture, religion, science, production, army, or society, representing

International connotation of the landscape historical aspects.
National, provincial or municipal connotation of the landscape historical aspects.
Local or contextual connotation of the landscape historical aspects. evolution. 
Table A4. Cont.

\begin{tabular}{|c|c|c|c|}
\hline Social Value & High Value & Medium Value & Low Value \\
\hline $\begin{array}{l}\text { Places for pleasure, } \\
\text { entertainment, rest, } \\
\text { observation, education, } \\
\text { health, or sports, } \\
\text { representing the social } \\
\text { and cultural dynamics of } \\
\text { individuals or groups of } \\
\text { people. }\end{array}$ & $\begin{array}{l}\text { Frequent attendance to places } \\
\text { for social interchange. }\end{array}$ & $\begin{array}{l}\text { Occasional attendance to } \\
\text { places for social interchange. }\end{array}$ & $\begin{array}{l}\text { No attendance to places for } \\
\text { social interchange. }\end{array}$ \\
\hline Scenic Value & High Value & Medium Value & Low Value \\
\hline \multirow{8}{*}{$\begin{array}{l}\text { Landscape with diversity } \\
\text { of natural and/or } \\
\text { anthropic components. } \\
\text { Characteristics of visual } \\
\text { gap in relation to } \\
\text { visibility and to the } \\
\text { visual, physical and } \\
\text { spatial components. }\end{array}$} & $\begin{array}{l}\text { Panoramic visual gap; } \\
\text { amplitude more than } 180 \\
\text { degrees. }\end{array}$ & $\begin{array}{l}\text { Panoramic visual gap; } \\
\text { amplitude from } 180 \text { to } 90 \\
\text { degrees. }\end{array}$ & $\begin{array}{l}\text { No panoramic visual gap; } \\
\text { amplitude less than } 90 \\
\text { degrees. }\end{array}$ \\
\hline & High visibility. & Medium visibility. & Low visibility. \\
\hline & $\begin{array}{l}\text { Landscape polychromy with } \\
\text { light and brilliant colors. }\end{array}$ & $\begin{array}{l}\text { Landscape polychromy with } \\
\text { dark and opaque colors. }\end{array}$ & $\begin{array}{l}\text { Absence of landscape } \\
\text { polychromy. }\end{array}$ \\
\hline & $\begin{array}{l}\text { Contrast of accentuated } \\
\text { textures. }\end{array}$ & Contrast of diffuse textures. & No texture contrasts. \\
\hline & Dominant scenic background. & $\begin{array}{l}\text { No dominant scenic } \\
\text { background. }\end{array}$ & No scenic background. \\
\hline & $\begin{array}{l}\text { Water as dominant element in } \\
\text { landscape. }\end{array}$ & $\begin{array}{l}\text { Water as no dominant element } \\
\text { in landscape. }\end{array}$ & No water in landscape. \\
\hline & $\begin{array}{l}\text { Continuous and accurate } \\
\text { edges among landscape } \\
\text { surfaces. }\end{array}$ & $\begin{array}{l}\text { Intermittent edges among } \\
\text { landscape surfaces. }\end{array}$ & $\begin{array}{l}\text { Diffuse edges among } \\
\text { landscape surfaces. }\end{array}$ \\
\hline & $\begin{array}{l}\text { Presence of natural and } \\
\text { anthropic milestones. }\end{array}$ & $\begin{array}{l}\text { Presence of natural or } \\
\text { anthropic milestones. }\end{array}$ & No milestones. \\
\hline
\end{tabular}

\section{References}

1. Western, D.; Mose, V.N.; Maitumo, D.; Mburu, C. Long-term changes in the plant ecology of an African savanna landscape and the implications for ecosystem theory and conservation management. Ecol. Process. 2021, 10, 1-12. [CrossRef]

2. NC 93-06-101 SNPMA. Paisaje. Términos y Definiciones. Sistema de Normas para la Protección del Medio Ambiente; Comité Estatal de Normalización: La Habana, Cuba, 1987; p. 15.

3. Quintela, J. El Inventario, el Análisis y el Diagnóstico Geo Ecológico de los Paisajes Mediante el Uso de los SIG. Ph.D. Thesis, Universidad de La Habana, La Habana, Cuba, 1995; p. 105.

4. Aguiló, M. Guía para la Elaboración de Estudios del Medio Físico. Contenido y Metodología; Ministerio de Obras Públicas y Transportes: Madrid, Spain, 1998; p. 484.

5. Salinas, C.E. Análisis y Evaluación de los Paisajes en la Planificación Regional en Cuba. Ph.D. Thesis, Facultad de Geografía, Universidad de La Habana, La Habana, Cuba, 1991; p. 187.

6. Salinas, E. Los Paisajes Como Fundamento del Ordenamiento Ambiental. Experiencias y Perspectivas; Convención Trópico: La Habana, Cuba, 2004.

7. Pérez-Chacón, E. Unidades de Paisaje: Aproximación Científica y Aplicaciones, en Paisaje y Ordenación del Territorio; Consejería de Obras Públicas y Transportes: Sevilla, Spain, 2006; p. 125.

8. Warnock, S.; Griffiths, G. Landscape Characterisation: The Living Landscapes Approach in the UK. Landsc. Res. 2014, 40, 261-278. [CrossRef]

9. MMA-IGAC. Zonificación Ecológica de la Región Pacífico Colombiano; Instituto Geográfico Agustín Codazzi: Santa Fé de Bogotá, Colombia, 2000; p. 365.

10. Escribano, B.R. "Propuesta de una Metodología para la Integración de las Actuaciones forestales en el Paisaje", en Paisaje y Ordenación del Territorio; Consejería de Obras Públicas y Transportes: Sevilla, Spain, 2006; p. 174.

11. Martínez, J.M.; Cárdenas, O.; Martín, G.; Olivera, J.; García, M. Guía Metodológica para los Estudios Técnicos de Ordenamiento Ambiental en Cuba; Ministerio de Ciencia Tecnología y Medio ambiente e Instituto de Geografía Tropical: La Habana, Cuba, 2009.

12. Ulrich, R.S. Visual landscapes and psychological well-being. Landsc. Res. 1979, 4, 17-23. [CrossRef]

13. Rodríguez, R. El Paisaje Urbano en el Centro Histórico de Santiago de Cuba: Método Gráfico Teórico para su Caracterización Morfotipológica. Ph.D. Thesis, Facultad de Construcciones, Universidad de Oriente, Santiago de Cuba, Cuba, 2008. 
14. Cambón, F.E.C. El Paisaje de la Cuenca Visual de la Bahía de Santiago de Cuba. Procedimiento Metódico para su Caracterización y Valoración. Ph.D. Thesis, Universidad de Oriente, Santiago de Cuba, Cuba, 2001.

15. Schmitz, S.; Vanderheyden, V. Reflexive loops on scaling issues in landscape quality assessment Serge Schmitz, Vincent Vanderheyden. Land Use Policy 2016, 53, 3-7. [CrossRef]

16. Steiner, F. The Living Landscape: An Ecological Approach to Landscape Planning, 2nd ed.; Island Press: Washington, DC, USA, 1991.

17. Scott, A. Assessing Public Perception of Landscape: The LANDMAP experience. Landsc. Res. 2002, 27, 271-295. [CrossRef]

18. Cambón, F.E.C. Proceso de urbanización y paisaje en la cuenca de la bahía de Santiago de Cuba. Rev. Arquit. Urban. 2011, XXXII, 3.

19. Willemen, L.; Verburg, P.H.; Hein, L.; Van Mensvoort, M.E. Spatial characterization of landscape functions. Landsc. Urban Plan. 2008, 88, 34-43. [CrossRef]

20. Mateo, R.J.M. Geoecología de los Paisajes. Apuntes Para un Curso de Postgrado; Universidad de los Andes: Mérida, Venezuela, 1991; p. 222.

21. Mateo, R.J.M. Geografía de los Paisajes; Universitaria de La Habana: Havana, Cuba, 2008; p. 436.

22. Olwig, K.R.; Dalglish, C.; Fairclough, G.; Herring, P.; Herring, P. Introduction to a special issue: The future of landscape characterisation, and the future character of landscape-between space, time, history, place and nature. Landsc. Res. 2016, 41, 1-6. [CrossRef]

23. Rojas, Á.; Ravelo, G. "Identificación de Valores en el Barrio de Colón", en El Barrio de Colón; Pontón Caribe, S.A., Ed.; Rehabilitación Urbana y Desarrollo Comunitario en La Habana: La Habana, Cuba, 2005; p. 40.

24. Martínez, P.E.; Ortega, C.N. (Eds.) Los Valores del Paisaje; Ediciones de la Universidad Autónoma de Madrid: Madrid, Spain, 2009; p. 322. ISBN 978-84-8344-151-0.

25. Muñoz, M.D.; Pérez, L.; Sanhueza, R.; Rovira, A.; Urrutia, R. Los paisajes del agua en la cuenca del río Baker: Bases conceptuales para su valoracion integral. Rev. Geogr. Norte Grande 2006, 36, 31-48. [CrossRef]

26. Nogué, J.; Sala, P. "El Paisaje en la Ordenación del Territorio. Los Catálogos de Paisaje de Cataluña", en Cuadernos Geográficos; University of Granada: Granada, Spain, 2008; pp. 69-98.

27. Mateu, J.F. "La Valoración Científica del Paisaje: Luis Pardo y los Lagos de España". en Los valores del Paisaje; Universidad Autónoma de Madrid: Madrid, Spain, 2009; pp. 155-161.

28. Recharte, J. "La Categoría de Reserva Paisajística como Estrategia de Conservación en el Contexto de Los Andes: Naturaleza y Cultura en la cordillera de Huayhuash, Perú", en Paisajes Culturales en Los Andes; Reunión de Expertos; UNESCO: Lima, Perú, 1998; pp. 131-140.

29. Pizano, O.; Cortés, R. "Paisajes Culturales, Territorio y Cultura en la Cordillera de Los Andes", en Paisajes Culturales en Los Andes; Reunión de Expertos; UNESCO: Lima, Perú, 1998; pp. 59-68.

30. Pinto-Correia, T.; Machado, C.; Barroso, F.; Picchi, P.; Turpin, N.; Bousset, J.-P.; Chabab, N.; Michelin, Y. How do policy options modify landscape amenities? An assessment approach based on public expressed preferences. Environ. Sci. Policy 2013, 32, 37-47. [CrossRef]

31. Brandt, J.; Tress, B.; Tress, G. (Eds.) Conference Material for the Conference on "Multifunctional Landscapes"; Centre for Landscape Research, University of Roskilde: Roskilde, Denmark, 2000.

32. Palmer, J.F.; Hoffman, R.E. Rating reliability and representation validity in scenic landscape assessments. Landsc. Urban Plan. 2001, 54, 149-161. [CrossRef]

33. Tveit, M.; Ode, A.; Fry, G. Key concepts in a framework for analysing visual landscape character. Landsc. Res. 2006, 31, 229-255. [CrossRef]

34. Carvalho-Ribeiro, S.; Loupa Ramos, I.; Madeira, L.; Barroso, F.; Menezes, H.; Pinto Correia, T. Is land cover an important asset for addressing the subjective landscape dimension. Land Use Policy 2013, 35, 50-60. [CrossRef]

35. Fairclough, G.J. Historic Landscape Characterisation: The State of the Art; English Heritage: London, UK, 1999.

36. Turner, S. Historic Landscape Characterization: A landscape archaeology for research, management and planning. Landsc. Res. 2006, 31, 385-398. [CrossRef]

37. Zube, E.H. Perceived land use patterns and landscape values. Landsc. Ecol. 1987, 1, 37-45. [CrossRef]

38. Mücher, C.A.; Klijn, J.A.; Wascher, D.M.; Schaminée, J.H. A new European Landscape Classification (LANMAP): A transparent, flexible and user-oriented methodology to distinguish landscapes. Ecol. Indic. 2010, 10, 87-103. [CrossRef]

39. Atik, M.; Işıklı, R.C.; Ortaçeşme, V.; Yıldırım, E. Exploring a combination of objective and subjective assessment in landscape classification: Side case from Turkey. Appl. Geogr. 2017, 83, 130-140. [CrossRef]

40. Allain, S.; Plumecocq, G.; Leenhardt, D. How Do Multi-criteria Assessments Address Landscape-level Problems? A Review of Studies and Practices. Ecol. Econ. 2017, 136, 282-295. [CrossRef]

41. Brabyn, L. Classifying Landscape Character. Landsc. Res. 2009, 34, 299-321. [CrossRef]

42. Venegas, C.; Rodríguez, J. “Valoración de los Paisajes Monumentales. Una Propuesta Metodológica para la Integración Paisajística de los Conjuntos Históricos", en Paisaje y Ordenación del Territorio; Consejería de Obras Públicas y Transportes: Sevilla, Spain, 2006.

43. Daniel, T.C. Whither scenic beauty? Visual landscape quality assessment in the 21st century. Landsc. Urban Plan. 2001, 54, 267-281. [CrossRef]

44. Mooser, A.; Anfuso, G.; Williams, A.T.; Molina, R.; Aucelli, P.P.C. An Innovative Approach to Determine Coastal Scenic Beauty and Sensitivity in a Scenario of Increasing Human Pressure and Natural Impacts Due to Climate Change. Water 2020, 13, 49. [CrossRef] 
45. Butler, A. Dynamics of integrating landscape values in landscape character assessment: The hidden dominance of the objective outsider. Landsc. Res. 2016, 41, 239-252. [CrossRef]

46. Rafael Calduch Métodos y Técnicas de Investigación Internacional. Madrid, 1998 (Revised and Updated Version. Madrid, 2014). Available online: https: / www.ucm.es/data/cont/docs/835-2018-03-01-Metodos\%20y\%20Tecnicas\%20de\%20Investigacion\% 20Internacional\%20v2.pdf (accessed on 10 June 2020).

47. Salomón, B.R.D. Metodología de la Investigación; McGraw-Hill Interamericana: NewYork, NY, USA, 2014; p. 92. ISBN 978-1-45622396-0/978-607-15-0291-9.

48. Stephenson, J. The Cultural Values Model: An integrated approach to values in landscapes. Landsc. Urban Plan. 2008, 84, 127-139. [CrossRef]

49. Birnbaum, C. Protecting Cultural Landscapes. Planning, Treatment and Management of Historic Landscapes; National Parks Service: Washington, DC, USA, 1994; Preservation Brief 36.

50. Martorell Carreño, Alberto: “Paisajes e Itinerarios Culturales: Conceptos Independientes que Enriquecen la Práctica de la Conservación Cultural". Available online: http:/ / www.esicomos.org/Nueva_carpeta/TCSM/ponencia_AMARTORELL.htm (accessed on 10 April 2010).

51. Pintó i Fosalba, J. El Paisaje de la Viña. Valor Cultural y Ambiental”, en Revista de Enología. 2015. Available online: http: //www.acenologia.com/ciencia95_1.htm (accessed on 12 July 2020).

52. Cantasano, N.; Caloiero, T.; Pellicone, G.; Aristodemo, F.; De Marco, A.; Tagarelli, G. Can ICZM Contribute to the Mitigation of Erosion and of Human Activities Threatening the Natural and Cultural Heritage of the Coastal Landscape of Calabria? Sustainability 2021, 13, 1122. [CrossRef]

53. Guirado Romero, José: "El Parque Natural Marítimo- Terrestre de Cabo de Gata-Níjar, un Espacio Excepcional". Available online: http:/ / ww.juntadeandalucia.es/cultura/iaph/infopha/05textose/boletin37.html (accessed on 10 June 2020).

54. Karrasch, L.; Maier, M.; Kleyer, M.; Klenke, T. Collaborative Landscape Planning: Co-Design of Ecosystem-Based Land Management Scenarios. Sustainability 2017, 9, 1668. [CrossRef]

55. ICOMOS. Viena Memorandun on "World Heritege and Contemporary Architecture-Managing the Historic Urban Landscape"; ICOMOS: Vienna, Austria, 2005.

56. UNESCO. Operational Guidelines for the Implementation of the World Heritage Convention. 2005. Available online: http: //whc.unesco.org/en/guidelines (accessed on 10 May 2020).

57. Mata, O.R.; Sanz, H.C. Atlas de los Paisajes de España; Ministerio de Medio Ambiente: Ambiente, Spain, 2003.

58. Ostle, B. Statistics in Research: Basic Concepts and Techniques for Research Workers; Literary Licensing: New York, NY, USA, 2012; p. 500, ISBN-10: 1258401649, ISBN-13: 978-1258401641.

59. Campos, G.C.; Lule, M.N. La observación, un método para el estudio de la realidad. Rev. Xihmai 2012, VII, 45-60.

60. Milanés, B.C.; Pacheco, A. Asentamientos costeros en la bahía de Santiago de Cuba: Estudio de su vulnerabilidad urbana. Rev. Arquit. Urban. 2011, XXXII, 18-26. Available online: http://es.scribd.com/doc/86054921/Revista-Arquitectura-y-Urbanismo-32011 (accessed on 10 April 2020).

61. Milanés, B.C. Método Integrado Para Demarcar y Delimitar las Zonas Costeras (DOMIZC): Estudio del Caso de Santiago de Cuba. Ph.D. Thesis, Universidad de Oriente, Santiago de Cuba, Cuba, 2014; p. 300. [CrossRef]

62. Botero, C.M.; Arrizabalaga, M.; Milanés, C.; Vivas, O. Indicadores de gobernabilidad para la gestión del riesgo costero en Colombia. Rev. Luna Azul. 2017, 45, 227-251. [CrossRef]

63. DPPF. Conjunto de Bases Cartográficas de la Provincia Santiago de Cuba; DPPF: Santiago de Cuba, Cuba, 2010; p. 78.

64. Cambón, F.E.C. Las múltiples miradas de la relación paisajística de Santiago con su bahía. Rev. Arquit. Urban. 2008, XXIX, 1.

65. Milanés, B.C. Unidades costeras ambientales para el manejo en Santiago de Cuba: Delimitación y prioridades de actuación. Rev. Arquitect. Urban. 2012, XXXIII, 83-97.

66. Batista, C.M.; Suárez, A.; Saltarén, C.M.B. Novel method to delimitate and demarcate coastal zone boundaries. Ocean Coast. Manag. 2017, 144, 105-119. [CrossRef]

67. Countryside Commission. Assessment and Conservation of Landscape Character: The Warwickshire Landscapes Project Approach; Countryside Commission: Cheltenham, UK, 1991.

68. Ministerio de Cultura. Ley No 2 de Monumentos de la República de Cuba. Protección del Patrimonio Cultural; Compilación de Textos Legislativos, Ed.; Consejo Nacional de Patrimonio Cultural, Ministerio de Cultura: La Habana, Cuba, 2002 ; p. 31.

69. Ministerio de Cultura. Decreto No. 55. Reglamento Para la Ejecución de la Ley de los Monumentos Nacionales y Locales; Compilación de Textos Legislativos, Ed.; Consejo Nacional de Patrimonio Cultural, Ministerio de Cultura: La Habana, Cuba, $2002 ;$ p. 67.

70. Milanes, C.B.; Pereira, C.I.; Botero, C.M. Improving a decree law about coastal zone management in a small island developing state: The case of Cuba. Mar. Policy 2019, 101, 93-107. [CrossRef]

71. Pereira, C.I.; Carvajal, A.F.; Milanés, B.C.; Botero, C.M. Regulating human interventions in Colombian coastal areas: Implications for the environmental licensing procedure in middle-income countries. Environ. Impact Assess. Rev. 2019, 79, 106284. [CrossRef]

72. Milanes, B.C.M.; Planas, J.A.; Pelot, R.; Núñez, J.R. A new methodology incorporating public participation within Cuba's ICZM program. Ocean Coast. Manag. 2020, 186, 105101. [CrossRef]

73. DPPF. Plan General de Ordenamiento Urbano de la ciudad de Santiago de Cuba; DPPF: Santiago de Cuba, Cuba, 2015; 134p.

74. Pérez, M.O.; Milanes, B.C. Social perception of coastal risk in the face of hurricanes in the southeastern region of Cuba. Ocean Coast. Manag. 2020, 184, 105010. [CrossRef] 
75. Marcos, L.S.O.; Tutikian, B.; Milanes, C.; Silva, F.O. Atmospheric contaminations and bad conservation effects in Roman mosaics and mortars of Italica. J. Clean. Prod. 2020, 248, 119250. [CrossRef]

76. Silva, L.F.O.; Milanés, C.; Pinto, D.; Ramirez, O.; Lima, B.D. Multiple hazardous elements in nanoparticulate matter from a Caribbean industrialized atmosphere. Chemosphere 2020, 239, 124776. [CrossRef] [PubMed]

77. Chris, D.; Alan, L. A question of what matters: Landscape characterisation as a process of situated, problem-orientated public discourse. Landsc. Res. 2016. [CrossRef]

78. Milder, J.C.; Buck, L.E.; DeClerck, F.A.J.; Scherr, S.J. Landscape approaches to achieving food production, natural resource conservation, and the millennium development goals. Integr. Ecol. Poverty Reduct. 2012, 77-108. [CrossRef]

79. Council of Europe. European Landscape Convention. 2000. Available online: http://conventions.coe.int/Treaty/en/Treaties/ html/176.htm (accessed on 21 December 2014).

80. Cosgrove, D. Social Formation and Symbolic Landscape; Croom Helm: London, UK, 1984.

81. Cosgrove, D. The Palladian Landscape: Geographical Change and its Cultural Representations in Sixteenth-Century; The Pennsylvania State University Press: Elkins Park, PA, USA, 1993.

82. Martín, B.; Ortega, E.O.; Arce, R.M. Landscape character assessment with GIS using map-based indicators and photographs in the relationship between landscape and roads. J. Environ. Manag. 2016, 180, 324-334. [CrossRef]

83. Brown, G.; Brabyn, L. An analysis of the relationships between multiple values and physical landscapes at a regional scale using public participation GIS and landscape character classification. Landsc. Urban Plan. 2012, 107, 317-331. [CrossRef]

84. Meeus, J.H.A.; Wijermans, M.P.; Vroom, M.J. Agricultural landscapes in Europe and their transformation. Landsc. Urban Plan. 1990, 18, 289-352. [CrossRef]

85. Alessa, L.; Kliskey, A.; Brown, G. Social-ecological hotspots mapping: A spatial approach for identifying coupled social-ecological space. Landsc. Urban Plan. 2008, 85, 27-39. [CrossRef]

86. Juntti, M.; Lundy, L. A mixed methods approach to urban ecosystem services: Experienced environmental quality and its role in ecosystem assessment within an inner-city estate. Landsc. Urban Plan. 2017, 161, 10-21. [CrossRef]

87. Bastian, O.; Krönert, R.; Lipský, Z. Landscape diagnosis on different space and time scales-A challenge for landscape planning. Landsc. Ecol. 2006, 21, 359-374. [CrossRef]

88. Termorshuizen, J.W.; Opdam, P.; Van den Brink, A. Incorporating ecological sustainability into landscape planning. Landsc. Urban Plan. 2007, 79, 374-384. [CrossRef]

89. Koschke, L.; Fürst, C.; Frank, S.; Makeschin, F. A multi-criteria approach for an integrated land-cover-based assessment of ecosystem services provision to support landscape planning. Ecol. Indic. 2012, 21, 54-66. [CrossRef]

90. Mann, C.; Garcia-Martin, M.; Raymond, C.M.; Shaw, B.J.; Plieninger, T. The potential for integrated landscape management to fulfil Europe's commitments to the Sustainable Development Goals. Landsc. Urban Plan. 2018, 177, 75-82. [CrossRef]

91. Jones, K.B.; Zurlini, G.; Kienast, F.; Petrosillo, I.; Edwards, T.; Wade, T.G.; Zaccarelli, N. Informing landscape planning and design for sustaining ecosystem services from existing spatial patterns and knowledge. Landsc. Ecol. 2013, 28, 1175-1192. [CrossRef]

92. Turner, M.G.; Crow, T.R.; Liu, J.; Rabe, D.; Rabeni, C.F.; Soranno, P.A.; Taylor, W.W.; Vogt, K.A.; Wiens, J.A. Bridging the gap between landscape ecology and nature resource management. In Integrating Landscape Ecology into Natural Resource Management; Liu, J., Taylor, W.W., Eds.; Cambridge University Press: Cambridge, UK, 2002; pp. 433-460.

93. Milanés, C.B.; Pérez, M.O.; Szlafsztein, C.F.; Pimentel, M.A.S. Climate change and spatial justice in coastal planning inCuba and Brazil. Ambiente Soc. 2020, 23, e01841. [CrossRef]

94. Kalinauskas, M.; Mikša, K.; Inácio, M.; Gomes, E.; Pereira, P. Mapping and assessment of landscape aesthetic quality in Lithuania. J. Environ. Manag. 2021, 286, 112239. [CrossRef]

95. Hermes, J.; Albert, C.; Von Haaren, C. Assessing the aesthetic quality of landscapes in Germany. Ecosyst. Serv. 2018, 31, $296-307$. [CrossRef]

96. Hermes, J.; Van Berkel, D.; Burkhard, B.; Plieninger, T.; Fagerholm, N.; Von Haaren, C.; Albert, C. Assessment and valuation of recreational ecosystem services of landscapes. Ecosyst. Serv. 2018, 31, 289-295. [CrossRef] [PubMed]

97. Durán, R.; Farizo, B.A.; Rodríguez, M.X. Conservation of maritime cultural heritahe: A discrete choice experiment in European Atlantic Region. Mar. Policy 2015, 51. [CrossRef]

98. Bauer, N.; Wallner, A.; Hunziker, M. The change of European landscapes: Humannature relationships, public attitudes towards rewilding, and the implications for landscape management in Switzerland. J. Environ. Manag. 2009, 90, 2910-2920. [CrossRef] [PubMed]

99. Batista, M.C. Coastal flood hazard mapping. In Encyclopedia of Coastal Science, 2nd ed.; Finkl, C.W., Makowski, C., Eds.; Springer Nature: Cham, Switzerland, 2018; Volume 1, pp. 471-479. [CrossRef]

100. Batista, M.C. Coastal risk. In Encyclopedia of Coastal Science, 2nd ed.; Finkl, C.W., Makowski, C., Eds.; Springer Nature: Cham, Switzerland, 2018; Volume 1, pp. 524-534. Available online: https:/ /link.springer.com/referenceworkentry/10.1007\%2F978-3-3 19-48657-4_408-1 (accessed on 28 April 2020).

101. Botero, C.M.; Pereira, C.I.; Milanes, C.B.; Pranzini, E. Dataset of human interventions as anthropogenic perturbations on the Caribbean coast of Colombia. Data Brief 2020, 31, 105847. [CrossRef]

102. Kalivoda, O.; Vojar, J.; Skřivanová, Z.; Zahradník, D. Consensus in landscape preference judgments: The effects of landscape visual aesthetic quality and respondents' characteristics. J. Environ. Manag. 2014, 137, 36-44. [CrossRef] 
103. Bürgi, M.; Ali, P.; Chowdhury, A.; Heinimann, A.; Hett, C.; Kienast, F.; Mondal, M.K.; Upreti, B.R.; Verburg, P.H. Integrated Landscape Approach: Closing the Gap between Theory and Application. Sustainability 2017, 9, 1371. [CrossRef]

104. Rodella, I.; Madau, F.A.; Carboni, D. The Willingness to Pay for Beach Scenery and Its Preservation in Italy. Sustainability 2020, 12, 1604. [CrossRef]

105. UNESCO. Cultural Heritage Protection Act. 1999. Available online: https://en.unesco.org/sites/default/files/slov_cultural_ heritage_protection_act_engtof.pdf (accessed on 25 June 2020).

106. Blanco, B.R. El sitio histórico Castillo del Morro San Pedro de La Roca en Santiago de Cuba: Exponente de la arquitectura hispánica. Batey Rev. Cubana Antropol. Sociocult. 2013, 5, 184-196.

107. Márquez, G.A.; Ortiz, P.B. Proyecto de Rehabilitación Integral de cayo Granma y su Entorno Ciencia en su PC, núm. 2; Centro de Información y Gestión Tecnológica de Santiago de Cuba: Santiago de Cuba, Cuba, 2005; ISSN 1027-2887.

108. Anfuso, G.; Williams, A.; Hernández, J.C.; Pranzini, E. Coastal scenic assessment and tourism management in western Cuba. Tour. Manag. 2014, 42, 307-320. [CrossRef]

109. Anfuso, G.; Williams, A.T.; Casas, G.M.; Botero, C.M.; Cabrera, J.A.; Pranzini, E. Evaluation of the scenic value of 100 beaches in Cuba: Implications for coastal tourism management. Ocean Coast. Manag. 2017, 142, 173-185. [CrossRef]

110. Danielle, K. Enfoque del Paisaje Sostenible. Guía de Implementación. Paisajes Sostenibles, División de Finanzas Conservación Internacional. 2018, p. 25. Available online: https://www.conservation.org/docs/default-source/publication-pdfs/ci_lafsustainable-landscape-approach-implementation-guidebook-spanish.pdf?Status=Master\&sfvrsn=56da1801_2 (accessed on 19 April 2021). 